\title{
ELITY BUŁGARSKIE PO PODBOJU BIZANTYŃSKIM. 1018-1041 R.*
}

\author{
JAROSEAW DUDEK
}

\begin{abstract}
The Bulgarian elites after the Byzantine conquest. 1018-1041.
Emperor Basil II, conquering Bulgaria in 1018, divided it into a province managed by Byzantine governors. The Bulgarian church remained under the authority of local priests. Members of the ruling Kometopouloi family received palace titles and appanages, while the other Bulgarian nobles maintained their possessions while serving in the imperial army. After two decades by minister John of Orphanotrophos, attempt to reduce their significance in local military structures and the property tax burden led to the creation of Peter Deljan in 1040-1041. The resignation of Byzantine authorities from damaging the prestige of the Bulgarian aristocracy contributed to the relief of the uprising.
\end{abstract}

STRESZCZENIE: Cesarz Bazyli II podbijając Bułgarię w 1018 r. podzielił ją na prowincje zarządzane przez bizantyńskich namiestników. Kościół bułgarski pozostał pod zwierzchnictwem miejscowych kapłanów. Członkowie panującego rodu Komitopulów otrzymali pałacowe tytuły i apanaże, zaś pozostali bułgarscy nobilowie utrzymali swoje posiadłości służąc równocześnie w armii cesarskiej. Podjęta po dwóch dekadach przez ministra Jana Orfanotrofa próba redukcji ich znaczenia w lokalnych strukturach wojskowych i obciążenie podatkowe majętności doprowadziło do powstania Piotra Deliana w 1040-1041. Rezygnacja władz bizantyńskich z decyzji szkodzących prestiżowi bułgarskiej arystokracji przyczyniła się do uśmierzenia powstania.

Author: Jarosław Dudek, Uniwersytet Zielonogórski, ul. Licealna 9, 65-417 Zielona Góra, Polska, e-mail: j.dudek@ih.uz.zgora.pl, ORCID iD: https://orcid.org/0000-0002-2895-2586

Keywords: Bulgaria, Byzantium, emperor Basil II, Kometopouloi dynasty, Bulgarian aristocracy in $11^{\text {th }}$ century, John the Orphanotrophos and his attempts at reform, Peter Deljan and the uprising in 1040-1041.

Słowa kluczowe: Bułgaria, Bizancjum, cesarz Bazyli II, dynastia Komitopulów, arystokracja bułgarska w XI w., Jan Orfanotrof i jego próby reform, Piotr Delian i powstanie w 1040-1041.

Balcanica Posnaniensia. Acta et studia, XXVI, Poznań 2019, Wydawnictwo Instytutu Historii UAM, pp. 43-71, ISBN 978-83-66355-32-3, ISSN 0239-4278. Polish text with summaries in English and Polish.

doi.org/10.14746/bp.2019.26.3

Położenie arystokracji bułgarskiej po 1018 r. było uwarunkowane okolicznościami podboju jej ojczyzny przez cesarza Bazylego II (976-1025), do dzisiaj nazywanego „Bułgarobójcą”. W pamięci historycznej współczesnych Bułgarów i Macedończy-

* Tekst powstał na bazie referatu wygłoszonego na konferencji pt. „Elity społeczne i polityczne na Bałkanach" zorganizowanej w ramach XVIII Balcanicum, UAM, Poznań 26-27 X 2018 r. 
ków okres prawie dwuwiekowego panowania bizantyńskiego nie utrwalił się wprawdzie tak traumatycznie jak prawie 500-letnia „niewola turecka”, pozostaje jednak postrzegany jako czas utraty narodowej suwerenności. Zapowiedzią bizantyńskiego jarzma jest obraz straszliwego pochodu 14 tysięcy ślepców - jeńców okaleczonych po klęsce w górach Bełasicy (29 VII 1014 r.) ${ }^{1}$. Postawę rodzimej elity w obliczu tej narodowej tragedii uznano za kapitulancką. Okazana cztery lata później manifestacja uległości bułgarskiej arystokracji miała świadczyć, o przyjęciu przez elity podbitego kraju postawy oportunistycznej ${ }^{2}$. Wyjaśnienie powodów rezygnacji bułgarskich nobilów z kontynuacji walki oraz starań o ułożenie swoich relacji ze zdobywcą wymaga jednak uwzględnienia kontekstu z wczesnośredniowiecznych dziejów różnych krajów chrześcijańskiej Europy.

Zaskakująca wydać się może likwidacja przez Bizancjum sąsiedniego państwa, którego monarchowie sto lat wcześniej osiągnęli stabilny status w ówczesnej hierarchii politycznej. Aneksja Bułgarii w 1018 r. była czymś nieczęstym na tle ówczesnej sceny politycznej. Owszem, w tych niespokojnych czasach dochodziło w świecie chrześcijan do wyniszczających wojen w trakcie których najeżdżano i pustoszono polityczne ośrodki przeciwnika. $Z$ reguły unikano jednak likwidacji pokonanych państw i unicestwiania ich elit. Zwycięzca najczęściej poprzestawał na zależności uchwytnej w ówczesnej symbolice polityczno-prawnej (np. narzucenie trybutu, statusu klientarnego) $)^{3}$. W X-XI w. kryzysy wewnętrzne niektórych organizmów politycznych

\footnotetext{
${ }^{1}$ Zob. m.in. S. S(iedlecka), Bazyli II Butgarobójca; S. B(arliewa), Bełasica; E. D(rzewiecka), Grek, G. S(zwat) - G(yłybowa), Niewola turecka, L. M(oroz) - G(rzelak), Samuel w: Leksykon tradycji bułgarskiej, red. G. Szwat-Gyłybowa, Warszawa 2011, s. 35-36, 102-104, 190-196, 262-264; L. Miodyński, Symbole miejsca w kulturze i literaturze macedońskiej, Katowice 2011, s. 184, 221-232; P. Majewski, (Re)konstrukcje narodu. Odwieczna Macedonia powstaje w XXI wieku, Gdańsk 2013, s. 45-47, 196-214, 234-239. Dla obecnych Bułgarów i Macedończyków wydarzenia te zaliczają się do okresu, traktowanego przez autora niniejszego tekstu jako etap ich wspólnej historii, niezależnie od specyfiki procesu rozwoju tożsamości obu tych bałkańskich narodów w czasach nowożytnych.

${ }^{2}$ Zwłaszcza w powojennej literaturze bułgarskiej powieści historycznej oraz w skryptach dziejów ojczystych jedenastowiecznych władców Bułgarii przedstawiano w kategoriach patriotycznych przywódców ludu zmagających się z bizantyńskimi najeźdźcami przeciwstawiając ich zabiegającym o materialne korzyści bojarom. Zob. W. Jóźwiak, Obraz początku i końca średniowiecznego państwa w bułgarskiej powieści historycznej z lat 1874-1989, Poznań 2017, s. 115-117. Por. Butgaria. Zarys dziejów, red. I. Dymitrow, Warszawa 1986, s. 58, gdzie poddających się cesarzowi nobilów uznano za kolaborantów prześcigających się w okazywaniu swej pokory".

${ }^{3}$ Uczynili to pogańscy Madziarowie wobec państwa wielkomorawskich Mojmirowiczów w pierwszych latach X w. Znikają wówczas dynastia, drużyna, rozpraszają się elity świeckie i kościelne. Zob. D. Treštík, Pád Velké Moravy, w: Typologie raně feudálních slovanských států. Sbornik přispěvkỉ z mezinárodni konferencje k tématu ,, Vznik a rozvoj slavanských raně feudálních státu a národností ve středni a jihovýchodni Evropě”, konané ve dnech 18.-20. listopadu 1986 v Praze, Praha 1987, s. 37-42. Ów wyjątek potwierdza jednak metody podboju praktykowane w chrześcijańskiej części Europy. Karol Wielki, najsłynniejszy zdobywca wczesnośredniowiecznej Europy, zajmując królestwo Longobardów (774) utrzymał jego status, podobnie stało z Akwitanią (781), również podbici Bawarowie (794) zachowali swoją odrębność administracyjno-militarną, prawną i kościelną od reszty królestwa Franków. Podobnie postąpiono wobec schrystianizowanych Sasów (785), zbliżone formy autonomii nadano zwyciężonym Awarom
} 
w Europie Środkowo-Wschodniej (Ruś, Czechy) zagroziły nawet ich dalszemu istnieniu (Polska, Węgry, Obodrzyci). Eliminacja rodów panujących nastąpiła w wypadku czeskich Sławnikowiców czy serbskich Wyszesławiczów. Zestawienie losu Bułgarii z tragicznym finałem powyższych lokalnych dynastów jako rezultatu kryzysu młodej państwowości jest nieodpowiednie ${ }^{4}$. Bułgaria była okrzepłym organizmem, którego elity wywodzące ze stepów pontyjskich, od końca VII w. wykazywały zadziwiającą zdolność do różnych form akomodacji: etnicznej (slawizacja), religijnej (chrystianizacja), politycznej (recepcja elementów bizantyńskiej idei cesarskiej, nawet parokrotnych zmian rodu panującego $)^{5}$.

Bizancjum przeżywa w drugiej połowie $\mathrm{X}$ w. wyraźny militarny i polityczny renesans. Po klęskach i utracie przed trzema wiekami najbogatszych wschodnich prowincji odnosi sukcesy w konfrontacji z muzułmanami i barbarzyńcami. Świadczą o tym terytorialne nabytki na wschodnim pograniczu, wyparcie Rusów znad dolnego Dunaju. W pierwszej połowie XI w. ten proces jest kontynuowany. Ormiańskie królestwa Bagratydów i Arcrunidów są kolejno anektowane, posiadłości w Italii konsolidowane. W przededniu śmierci Bazylego II (15 XII 1025 r.) przygotowywano ekspedycję na Sycylię. Konsekwencje powyższych nabytków dla Bizancjum i jego elit ostatecznie okażą się mniejsze niż przywrócenie starej granicy na Dunaju.

Bułgaria była istniejącą od prawie trzech wieków monarchią, której byt od przyjęcia chrztu w 866 r., z punktu widzenia bizantyńskiej ortodoksji politycznej nie został wyraźnie określony jako sprzeczny z dziejowym przeznaczeniem Nowego Rzymu, co m.in. wykazywało umieszczenie jej władców w bizantyńskiej rodzinie monarchów ${ }^{6}$. Ponadto, brak oznak wewnętrznego załamania państwa bułgarskiego. Położenie gospodarcze poddanych następców Symeona I Wielkiego (893-927) nie uległo pogorszeniu, trudno dostrzec również poważniejsze wstrząsy społecznych czy sporów wśród elit przed 971 r. $^{7}$ Uwieńczony cesarską koroną autorytet monarchii nie był kwestionowany przez poddanych. Światosław z Kijowa (945-972), niedoszły zdobywca Bułgarii,

(791-803) usiłując wyznaczyć im nowych chrześcijańskich przywódców (kagana Abrahama i kavcha$n a$ Teodora). W tych okolicznościach prawie wszystkie podbite królestwa i ludy funkcjonowały dalej jako peryferyjne władztwa zarządzane na wzór frankijski. Zob. R. McKitterick, Królestwa Karolingów. Władza - konflikty - kultura. 751-987, przekł. B. Hlebowicz, M. Wilk, Warszawa 2011, s. 73, 83-91, 121; W. Pohl, Die Awaren. Ein Steppenvolk in Mitteleuropa. 567-822 n. Chr., München 1988, s. 204 205, 320-323.

${ }^{4}$ A. Pleszczyński, Kryzys i upadek wczesnych państw stowiańskich oraz ich odbudowa (IX-XI wiek). Zarys problemu, „Kwartalnik Historyczny”, 125, 2018, 2, s. 267-271.

${ }^{5}$ D. Ziemann, Between authoritarianism and consensus. Domination and the role of nobility in the First Bulgarian Realm (7th $-9^{\text {th }}$ Century), "Bulgaria Mediaevalis", 2, 2011 (1), s. 373-397.

${ }^{6}$ M.J. Leszka, Wizerunek władców pierwszego państwa bułgarskiego w bizantyńskich źródłach pisanych (VIII - pierwsza połowa XII wieku), Łódź 2003, s. 145-146.

${ }^{7}$ M.J. Leszka, K. Marinow, Carstwo bułgarskie. Polityka - społeczeństwo - gospodarka - kultura. 866-971, Warszawa 2015, s. 277-304; M.J. Leszka, K. Marinow, The Internal Situation, w: The Bulgarian State in 927-969. The Epoch of Tsar Peter I, ed. M.J. Leszka, K. Marinow, Łódź-Kraków 2018, s. 91109; K. Marinov, The Economy, w: tamże, s. 203-222. 


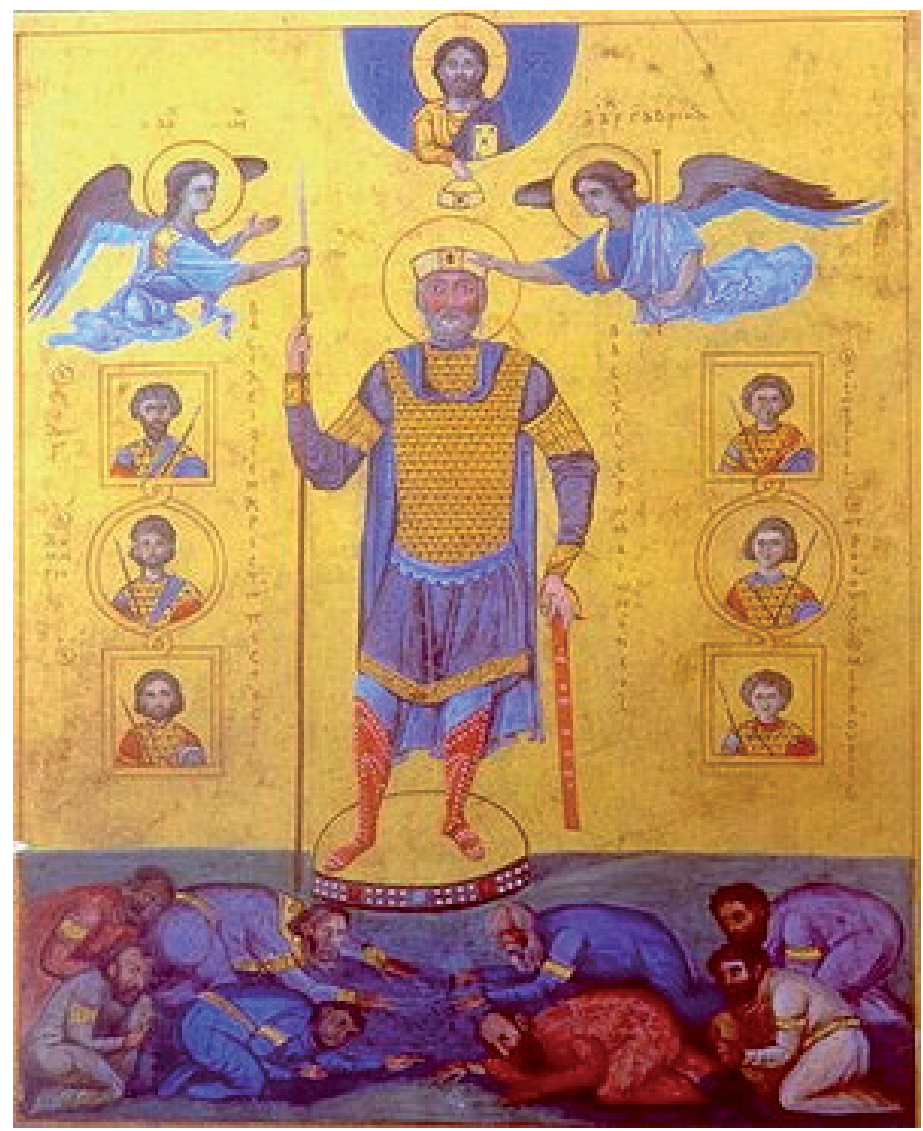

Il. 1. Bazyli II i nobilowie (bułgarscy) w geście proskynezy, miniatura z psałterza Bazylego II (Marc. grec. 19)

Źródło: domena publiczna: bg.wikipedia.org/wiki/Василий_II_Българоубиец [pobranie 07.11.2018]

aby móc kontrolować pokonanych utrzymał na tronie cara Borysa II (969-971). Z kolei Jan I Tzymiskes (969-976), przystępując do wojny z Rusami podkreślał swoją rolę ,wyzwoliciela” cara, jego rodziny i poddanych spod pogańskiego jarzma. Podjęta po pokonaniu Światosława próba aneksji (detronizacja Borysa II, utworzenie nowych prowincji nad dolnym Dunajem, narzucenie nie sprecyzowanych form zwierzchności zachodnim komitatom) nie doprowadziła do ustanowienia na ziemiach bułgarskich trwałego pax byzantina. Kolejna wojna, rozpoczęta w przedostatniej dekadzie X w., potwierdziła iluzoryczność rozwiązań Tzymiskesa ${ }^{8}$.

${ }^{8}$ Zob. C. Пириватрић, Самуилова држава. Обим и карактер, Београд 1997, s. 53-57; В. Krsmanović, The Byzantine Province in Change (On the Treshold Between the $10^{\text {th }}$ and $11^{\text {th }}$ Century, Belgrade 2008, s. 132-148. Były nieskuteczne, nawet zakładając, że niektórzy z poprzedników Bazylego II plano- 


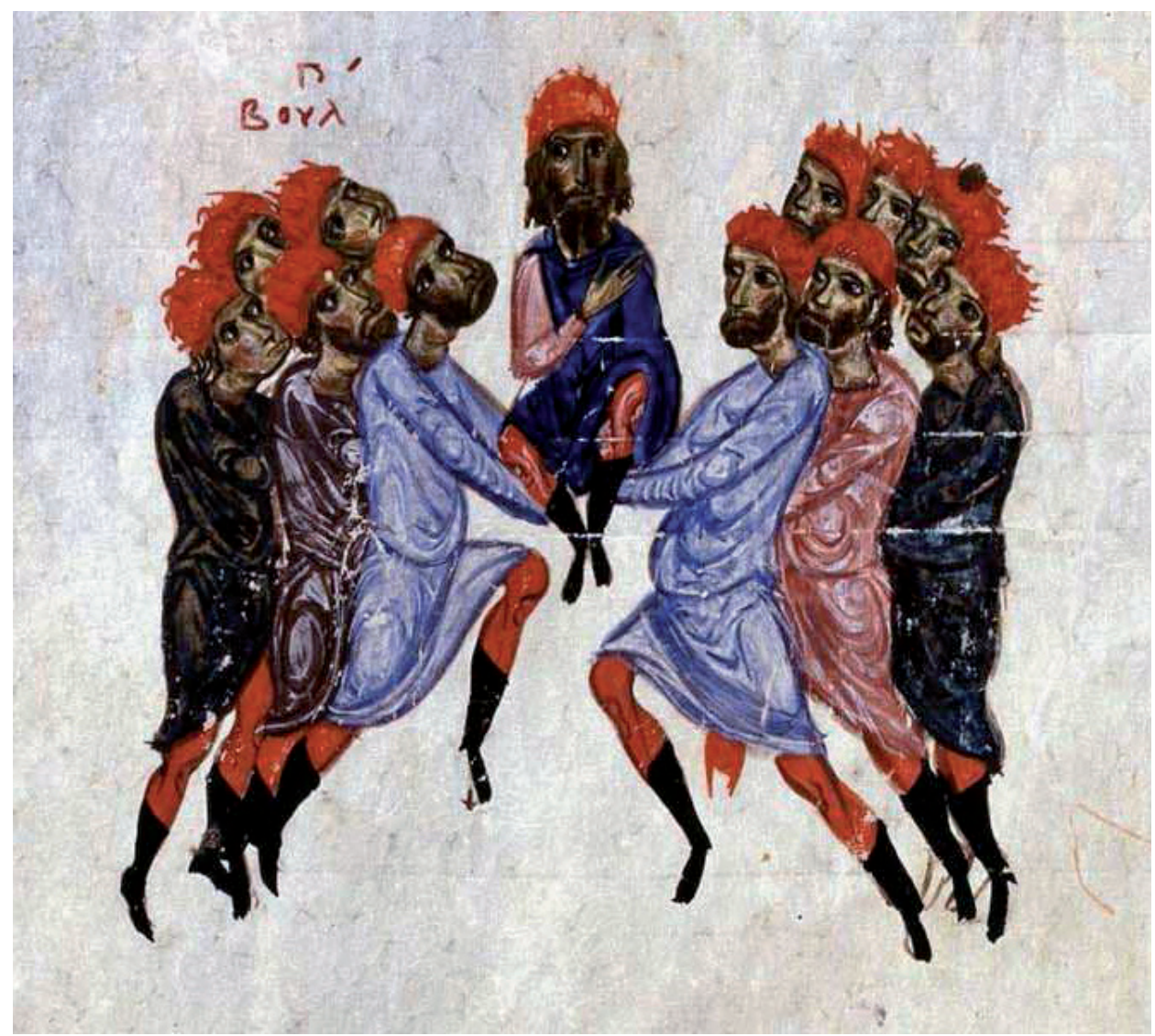

Il. 2. Intronizacja Deliana, miniatura z madryckiego rękopisu kroniki Jana Skylitzesa (Matritensis II). Źródło: domena publiczna: bg.wikipedia.org/wiki/Въстание_на_Петър_Делян/

[pobranie 07.11.2018]

Aneksja północnego chrześcijańskiego sąsiada w 1018 r. w pierwszej kolejności była wyzwaniem ideowym, w następnej administracyjnym. Obu musiał sprostać Bazyli II i jego doradcy. Sukcesorom zdobywcy, młodszemu bratu Konstantynowi VIII (1025-1028) czy bratanicom: Zoe (1028-1055) i Teodorze (1042-1056), kolejnym cesarzom-mężom pierwszej z tych władczyń: Romanowi III Argyrosowi (1028-1036), Michałowi IV Paflagończykowi (1036-1041), pozostała już tylko modyfikacja zarządzania. Jednak i w tym wypadku administrowanie przyłączonymi terytoriami na niższym szczeblu wymagało wsparcia ze strony lokalnych elit. Eliminacja czy marginali-

wali częściową aneksję Bułgarii. Zob. J. Bonarek, Przyczyny i cele bułgarskich wypraw Świętosława a polityka Bizancjum w latach sześćdziesiątych X wieku „Studia Historyczne”, 39, 1996, 3, s. 287-302. 
zacja Bułgarów była z różnych przyczyn (wspólnota religii, gospodarka bałkańskiego interioru) niemożliwa w realizacji ${ }^{9}$.

Pierwsze dwie dekady po podboju trzeba uznać za wstęp dla ustanowienia zrębów nowego porządku. Nadal pozostawali aktywni nobilowie pamiętający czasy dawnego carstwa oraz przywiązani do swojego dotychczasowego stylu życia. Odczuwalne były zapewne również konsekwencje zmian wywołanych długoletnią i podbojem. Za punkt wyjścia należy uznać luty 1018 r., kiedy po śmierci cara Jana Władysława szybko ustaje opór i bułgarskie elity kapitulują. Natomiast za zamknięcie procesu formowania się pax byzantina trzeba uznać powstanie Deliana w 1040-1041 r., które przybrało postać regularnej wojny. Zdaniem niektórych Bizantyńczyków jego zdławienie urosło nawet do rangi ponownego podboju. Oba wydarzenia są symboliczne, co w sferze wizualnej odzwierciedlają dwie miniatury powstałe w kręgu sztuki bizantyńskiej. Na pierwszej z nich dostrzec można (bułgarskich?) nobilów korzących się w geście proskynezy przed Bazylim II, natomiast na drugiej zbuntowani bułgarscy wodzowie podnosząc Deliana intronizują rodzimego władcę ${ }^{10}$.

Bliższe spojrzenie pozwala dostrzec złożoność problemu związanego z postawą elit bułgarskich wobec bizantyńskiego panowania w latach 1018-1040. Badania nad relacjami bizantyńsko-bułgarskimi we wczesnym średniowieczu mają już swoją tradycję ${ }^{11}$. Jednak zdecydowana większość tekstów bezpośrednio poświęcona temu zagadnieniu dotyczy wzajemnych kontaktów międzypaństwowych w dłuższym lub

${ }^{9}$ Bazyli II i jego następcy nie brali nawet pod uwagę radykalnych rozwiązań podjętych przez Borysa Michała w latach 865-866. Ówczesny władca Bułgarów tłumiąc bunt wywołany przyjęciem przezeń chrześcijaństwa uśmiercił 52 nobilów włącznie z rodzinami. Prawdopodobnie straceni zaliczali się do starej arystokracji, powiązanej z pogańskimi, stepowymi tradycjami starobułgarskimi. Ich fizyczna eliminacja, połączona z konfiskatą mienia, umożliwiła Borysowi Michałowi przebudowę elit bułgarskich wraz z konsolidacją pełni władzy. Zob. D. Ziemann, The rebellion of the nobles against the baptism of Khan Boris (865-866), w: Post-Roman Towns, Trade and Settlement in Europe and Byzantium. Vol. 2. Byzantium, Pliska, and the Balkans, ed. J. Henning, Berlin - New York 2007, s. 613-624.

${ }^{10} \mathrm{~W}$ pierwszym wypadku jest to miniatura z tzw. „Psałterza Bazylego II”, którego rękopis (Marc. gr. 17) jest obecnie przechowywany w Bibliotece Marcjańskiej w Wenecji. Prawdopodobnie powstał ok. 1019 r., twórca mógł być jednym z artystów uczestniczącym w ilustrowaniu starszego manuskryptu (Vat. grec. 1613), tzw. „Menologionu Bazylego II”, gdzie pojawia się postać władcy w identycznym ujęciu, z tym, że korzące się przed nim postacie niekoniecznie mogą być utożsamiane z Bułgarami, aczkolwiek Bazyli II prowadził z nimi intensywne wojny już od końca lat 80-tych X w. Zob. I. Ševčenko, The Illuminators of the Menologium of Basil II, „Dumbarton Oaks Papers”, 16, 1962, s. 345-276, zwłaszcza, s. 272-273, il. nr 17; N.P. Š(evčenko), Menologion of Basil II, w: ODB, t. 2, s. 1341-1342; P. Ł. Grotowski, Święci wojownicy w sztuce bizantyńskiej (843-1261), Kraków 2011, s. 382-383; W drugim wypadku jest to miniatura zamieszczona w tzw. madryckim rękopisie (Matritensis II) kroniki Jana Skylitzesa. Podkreślić należy, że obie te miniatury nie powstały w Bułgarii i nie ilustrują bezpośrednio konkretnych przedstawicieli jej elit.

11 Zob. В. Златарски, Устройство Болгарии и положение болгарского народа в первое время после покорения их Василием II Болгаробойцею, „Seminarium Kondakovianum”, t. 4, Praha, 1931, s. 49-67, [przedruk: В. Златарски, Избрани произведения, t. II, София 1984, s. 120-140]. 
krótszym okresie historycznym ${ }^{12}$, statusu Bułgarów w Bizancjum ${ }^{13}$, wizerunków konkretnych Bułgarów uchwyconych w określonym czasie czy w konkretnym źró$\mathrm{dle}^{14}$. Prace o bułgarskiej elicie, odnoszą się jednak raczej do czasów wcześniejszych czy całego okresu niewoli bizantyńskiej ${ }^{15}$.

Może się to wydać zaskakujące z racji obszernego zasobu źródeł narracyjnych bizantyńskich ${ }^{16}$ oraz rodzimych $^{17}$. Z tekstów normatywnych zachowały się listy buł-

12 Odnieść to można zarówno do rodzimej historiografii oraz obcej. Zob. И. Божилов, Б. Гюзелев, История на средновековна България VII-XIV век, София 1999; S. Runciman, A history of the first Bulgarian empire, London 1930; R. Browning, Byzantium and Bulgaria. A Comparative Study across the Early medieval Frontier, London 1975; M.J. Leszka, Symeon I Wielki a Bizancjum. Z dziejów stosunków butgarsko-bizantyńskich w latach 893-927, Łódź 2013; The Bulgarian State in 927-969. The Epoch of Tsar Peter I, ed. M.J. Leszka, K. Marinow, Łódź-Kraków 2018.

${ }^{13}$ И. Божилов, Българите във византийската империя, София 1995, s. 72-80, 89-93, 108-118; В.П. Степаненко, Владиславичи, Арируниды и Багратиды в Византии ХI в., „Античная древость и средние века", 43, 2015, s. 178-191.

${ }^{14} \mathrm{~Np}$. J. Bonarek, Romajowie i obcy w kronice Jana Skylitzesa. Identyfikacja etniczna Bizantyńczyków i ich stosunek do obcych w świetle kroniki Jana Skylitzesa, Toruń 2003, 119-123, 128-156; M.J. Leszka, Gabriel Radomir (1014-1015) i Jan Władystaw (1015-1018), władcy państwa butgarskiego w źródtach bizantyńskich, „Balcanica Posnaniensia. Acta et studia”, 25, 2018, s. 43-51.

15 Zwłaszcza Г. Н. Николов, Централизъм и регионализм в ранносредновековна България, София 2005, s. 123-206. Podobnie В. Тьпкова-Заимова, „Българи родом...”. Комитопулите, цар Самуил и неговите потомци според историческите извори и историогрфската традиция, София 2014. Por. Г.Г. Литаврин, Болгария и Византия в XI-XII вв., Москва 1960, s. 73-175, 249-309, 351-375; А.П. Каждан, Социальный состав господствующего класса Византии XI-XII вв., Москва 1974, 140-220 (na tle bizantyńskiej arystokracji); C. Schulz, Probleme bei der Erforschung der Integration Bulgariens in das Byzantinische Reich, 1018-1186, w: Zwischen Polis, Provinz und Peripherie. Beiträge zur byzantinischen Geschichte und Kultur, ed. L.M. Hoffmann, A. Monchizadeh, Wiesbaden 2005, s. 337-347; А. Добычина, „Под одним ярмом” с Византией: болгары и болгарские земли в составе Византийской империй (1018-1185), w: Българско иарство. Сборник в чест на 60-годишнията на дои. д-р Георги Н. Николов, (REGNUM BULGARIAE. Studia in honorem annorum LX Georgii N. Nikolov), отговорен редактор доц. А. Николов, София 2018, s. 476-497, przedstawiają tę kwestie raczej lakonicznie, natomiast C. Пириватрић, Самуилова држава, dz. cyt, s. 168180 lub G.N. Nikolov, The Bulgarian aristocracy in the war against the Byzantine Empire (971-1019), w: Byzantium and East Central Europe, ed. G. Prinzing, M. Salamon, P. Stephenson, Cracov 2001, s. 141-158, skupiają się na okresie sprzed 1018 r. Szereg istotnych spostrzeżeń do tego problemu można dostrzec w wystąpieniach autorów referatów wygłoszonych na kongresie w Sofii w październiku 2014 r., zorganizowanym z racji 1000-lecia bełasickiej bitwy i śmierci cara Samuela. Zostały one opublikowane pod redakcją Wasyla Gjuzelewa i Georgi Nikołowa w formie tomu materiałów pokonferencyjnych: Европейският Югоизток през втората половина на X-началото на ХI век. История и култура, София 2015.

${ }^{16}$ Spośród źródeł narracyjnych za szczególnie ważne świadectwo należy uznać kronikę Jana Skylitzesa (Zarys dziejów) opisującą dzieje panowania cesarzy w latach 811-1057. Autor urodził się ok. 1040 r., zmarł w pierwszej dekadzie XII w. Tekst Zarysu dziejów napisał w latach 70-tych XI w., anonimową kontynuację, przez niektórych badaczy przypisywaną Skylitzesowi, sporządzono krótko przed $1081 \mathrm{r}$. Zob. Ioannis Synopsis historiarum, ed. H. Thurn, Berlin - New York 1973; Hē synecheia tēs Chronographias tou Iōannou Skylitsē (Ioannes Skylitzes Continuatus), ed. Th. Tsolakēs, Thessalonike 1968. Oba teksty były interpolowane, co potwierdza wiedeński rękopis kroniki i jej kontynuacji (Cod. Vind. Hist. Gr. 74). Ma to istotne znaczenie $\mathrm{w}$ wypadku położenia ówczesnych elit bułgarskich, ponieważ autorem uzupełnień 
garskich biskupstw i hierarchów: sigilliony Bazylego II i tzw. katalog Du Cange’a. Pierwszy z tych zestawów, powstał bezpośrednio po podboju i stanowi cenną ilustrację materialnego status bułgarskich hierarchów w latach 1019-102018. Drugie dostarcza danych o pochodzeniu arcybiskupów rezydujących w Ochrydzie ${ }^{19}$. Oba źródła sporadycznie wspominają mnichów bułgarskich, chociaż niektóre z monasterów przetrwały upadek państwa. Na tę społeczność polityczne zmiany bezpośrednio nie wpłynęły, nie przeszkadzało to jednak jej członkom w komentowaniu aktualnej rze-

był biskup dewolski Michał (pocz. XII w.) dobrze zorientowany w realiach jedenastowiecznych zachodnich Bałkanów. Zob. И. Илиев, Добавки на епископ Михаил Деволски от 1118 г. към „Исторически свод” на Йован Скилица (XI в.), w: В. Гюзелев, Извори за средновековната история България (VIIXVв.) в австрийските ръкописни сбирки и архиви. Първи том. Български, други славянски и византийски извори, София 1994, s. 45-57; J. Ferluga, John Scylitzes and Michael of Devol, w: tegoż, Byzantium on the Balkans. Studies on the Byzantine Administration and the Southern Slavs from the VII ${ }^{\text {th }}$ to the XII ${ }^{\text {th }}$ Centuries, Amsterdam 1976, s. 337-344.

Informacje zawarte w pierwotnej wersji „Zarysu dziejów” pochodzą z różnych tekstów. Dane do panowania Bazylego II, zaś w szczególności opis podboju Bułgarii i wprowadzenia w niej nowych porządków, Skylitzes zaczerpnął z zaginionej pracy biskupa Teodora z Sebastii. Opisując późniejsze lata wykorzystał wymienione tylko przez niego zapiski biskupa Demetriusza z Kyzikos i mnicha Jana Lydosa. Krytyczny stosunek Skylitzesa wobec cesarzy paflagońskich oraz ich krewnych, to zapewne rezultat zapożyczeń od niechętnych im autorów z połowy XI w. Zob. A. K(azhdan), Scylitzes Continuatus, w: t.3, s. 1914. Por. J.-C. Cheynet, Récrire l'Histoire: la "Synopsis" de Jean Skylitzès, w: Jean Skylitzès. Empereurs de Constantinople, trad. B. Flusin, Paris 2003, s. XII-XVI; B. Holmes, Basil II and the Governance of Empire (976-1025), Oxford 2005, s. 91-119; zwłaszcza J. Shepard, A suspected source of Scylitzes? "Synopsis Historion": the great Catacalon Cecaumenus, "Greek, Roman and Byzantine Studies", 18, 1992, s. 171-181.

${ }^{17}$ Pozostają one zauważalne pomimo dysproporcji w porównaniu ze źródłami bizantyńskimi. Jako reakcję na nastanie nowego porządku można potraktować takie utwory jak: „Opowieść proroka Izajasza” lub „Bułgarska kronika apokryficzna. Słowo proroka Izajasza, jak został przez anioła wyniesiony do siódmego nieba" (Сказание за светия пророк Исайя за бъдните години и за ияарете, и за Антихриста, който ще дойде; Български апокрифен летопис. Сказание на пророк Исайа как бе възнесен от ангел до седмоте небе). $\mathrm{O}$ ich autorach nie wiemy niemal nic, prawdopodobnie byli mnichami ze środkowej Bułgarii. Zob. В. Тапкова-Заимова, А. Милтенова, Историко-апокалиптична книжнина във Византия и в средовековна България, София 1996, s. 25, 139-160, 192-206; И. Билярски, Сказание на Исайа пророка и формирането на политическата идеология на ранносредновеквна България, София 2011, s. 181-185; G. Minczew, M. Skowronek, Apokryfy i legendy starotestamentowe Stowian potudniowych, Kraków 2006, s. 62-69.

${ }^{18}$ Trzy sigiliony kolejno wystawione przez cesarską kancelarię przypuszczalnie w 1020 r. potwierdzone chryzobullą cesarza Michała VIII Paleologa z 1272 r. Zob. Й. Иванов, Български старини из Македония, София 1970, s. 547-562, zwłaszcza s. $555_{4-5}, 556_{1-3,29-31}, 558_{28-29}$. Por. Regesten der Kaiserukunden des oströmischen Reiches von 565-1453, berabeitet von F. Dölger, A.E. Müller, A. Beihammer, 1 Teil, 2 Halband Regesten 867-1025, München 2003, nr 806, 807, 808; berabeitet von F. Dölger, Teil 3. Regesten 1204-1282, München - Berlin 1932, nr 1992; Sigiliony Bazylego II, w: Testimonia Najdawniejszych Dziejów Stowian, z. 4, Pisarze z VIII-XII wieku, red. A. Brzóstkowska, W. Swoboda, Warszawa 1997, s. 105-123.

19 Й. Иванов, Български старини из Македония, dz. cyt., s. 564-568; Zob. V. Tăpkova-Zaimova, The Du Cange Catalogue, w: State and Church. Studies in Mediewal Bulgaria and Byzantium, ed. by V. Gjuzelev and K. Petkov, Sofija 2011, s. 209-235; И. Божилов, Българската архиепископия XIXII век, dz. cyt., s. 101-105; Katalog Du Cange'a, w: Testimonia, z. 4, s. 124-132. 
czywistości ${ }^{20}$. Niestety, źródła sfragistyczne w ograniczonym zakresie mogą być wykorzystane w badaniach nad pierwszą fazą panowania bizantyńskiego. Kiedy nie można zweryfikować tożsamości ich wystawców wówczas precyzyjna datacja jest niemożliwa, odzwierciedlają raczej dłuższą perspektywę czasową ${ }^{21}$.

Pozornie u zarania nowego porządku w podbitym kraju wyłania się obraz wyniszczonego kraju i społeczeństwa znużonego długotrwałą i ciężką wojną. Wydają się to m.in. odzwierciedlać opisane pół wieku później zarządzenia autokratora:

Plemię Bułgarów w wyniku licznych niebezpieczeństw i walk [...] stało się częścią Cesarstwa Rzymskiego, kiedy ów sławny władca Bazyli uczynił z ich ziem, jak to się mówi, zdobycz ( $\lambda a ́ \mu \phi a \nu \tau o \varsigma ~ \lambda \epsilon i$ av) i zniszczył ich siłę 22 . (Przekł. O. Jurewicz).

Bazyli II nie ofiarował pokonanym autonomii, jak to ongiś sugerowali niektórzy badacze, sugerując nawet utrzymanie Bułgarii w dotychczasowych granicach jako autonomicznej prowincji Cesarstwa ${ }^{23}$. Zdobywca, w przeciwieństwie do cesarzy Franków czy władców Rzeszy, mógł zarządzać zdobytymi ziemiami poprzez własnych dygnitarzy. Cesarz wprost oznajmiał w jednym z dokumentów, że ,pprzez rozszerzenie władzy Romajów także Bułgarzy znaleźli się pod tym samym jarzmem

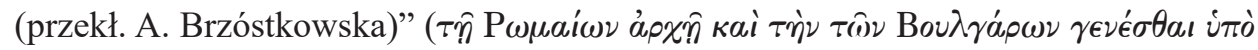

${ }^{20}$ Podobnie, jak w wypadku hierarchii episkopalnej, nie zachowały się dokumenty nadań na rzecz instytucji monastycznych pochodzące sprzed 1018 r. Należy jednak przyjąć, że mnisi cieszący się poważaniem u bułgarskich władców (pod koniec życia Borys-Michał i Piotr I, w młodości Symeon Wielki oraz ich najbliżsi składali mnisze śluby) i dygnitarzy, otrzymywali odpowiednie materialne wsparcie. Trudno sprecyzować wkład Komitopulów dla monastycyzmu bułgarskiego, w przeciwieństwie do członków starej dynastii brak danych o ich zaangażowaniu w klasztorne życie przed 1018 r. Z pierwszych dekad po podboju nie zachowały się żadne informacje o nowych klasztorach. Pierwsze zachowane typikony na ziemiach bułgarskich pochodzą dopiero z drugiej połowy XI w. Zob. Б. Николова, Монашество, манастири и манастирски живот в средновековна България, София 2010, t. I, Монастирите, s. 13-14, 41-43, 46-49, 188-190, 256-263; t. II, Монасите, s. 559-563, 570-571, 578-595, zwłaszcza 846-849; M.J. Leszka, K. Marinow, Carstwo butgarskie, dz. cyt., s. 256-262.

21 В. Тъпкова-Заимова, „Българи родом..., ”, dz. cyt., s. 303-307. Zob. И. Йорданов, Печати на потомцчите на цуар Иван Владислав (1016-1018) в Византии, „Археология”, 1996, nr 4, s. 7-22.

22 Mich. Psell., IV 39, s. $76_{1-4}$; Michał Psellos, Kronika czyli historia jednego stulecia Bizancjum (976-1077), przekł. O. Jurewicz, Wrocław-Warszawa 1985, s. 52. W podobnym duchu wypowiada się Jan Zonaras, Epitomae historiarum libri XIII-XVIII, XVII 17, ed. Th. Büttner-Wobst, Bonnae 1897, s. 598 11-11. Skylitzes (s. 363-365) poświęca wiele uwagi celebracji zwycięstwa, nie omieszka jednak podkreślić, że cesarz wyznaczył zarządców zdobytych ziemi i wydzielił im pod komendę oddziały wojska. Paul Stephenson (The Legend of Basil the Bulgar-Slayer, Cambridge 2003, s. 90-95) podkreśla, że przydomek „Bułgarobójcy” zdobywa popularność u autorów bizantyńskich, mimo wcześniejszych adnotacji, dopiero pod koniec XII w. Por. J. Dudek, Cesarz Bazyli II w opiniach średniowiecznych Bułgarów, w: Stereotypy bałkańskie. Księga jubileuszowa Profesor Ilony Czamańskiej, red. J. Paszkiewicz, Z. Pentek, Poznań 2011, s. 62-85; A. Nikolov, On Basil II's cognomen ,, The Bulgar-Slayer”, w: Европейският Югоизток, s. 581 .

${ }^{23}$ Np. В. Златарски, Устройство Болгарии, dz. суt., s. 121-126. 


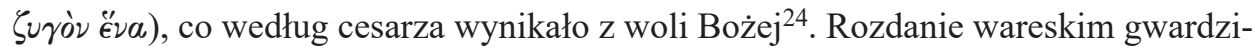
stom zawartości ochrydzkiego skarbca carów było nie tylko manifestacją hojności zwycięscy, odzwierciedla również potraktowanie w kategoriach łupu wojennego jednego $\mathrm{z}$ instytucjonalnych symbolu podbitego państwa ${ }^{25}$. Manifestacja takich gestów podkreślała skalę zwycięstwa, niekoniecznie jednak świadczyła o dążeniu do pognębienia elit Bułgarów. Dostrzec to można na przykładzie decyzji cesarza związanych z sferami życia świeckiego i kościelnego podbitego kraju.

Bazyli II podzielił Bułgarię na namiestnictwa, częściowo tylko powielając rozwiązania Jana Tzymiskesa z okresu między 971 a 976 r. Niektóre z regionów Bułgarii włączono do starych bizantyńskich prowincji (Adrianopol, Tesalonika), założono nowe (Skopje), zaś w kolejnych latach rozbudowywano następne prowincje (Sirmium, Dyrrachion, Paradunavon) ${ }^{26}$. Na stanowiska zarządców (strategów, katepanów lub duksów) cesarz powołał pochodzących spoza Bałkanów, lojalnych zahartowanych w wojnach, weteranów. Następcy Bazylego II powierzali je stołecznym lub anatolijskim notablom. Brak świadectw, aby którykolwiek z tych dygnitarzy wywodził się z miejscowych elit ${ }^{27}$. Dopiero od połowy XI w., w Adrianopolu, w Paradunavon (Paristrion), w Dyrrachion, widzimy gubernatorów (np. Mikołaj Chryselios) pochodzących z lokalnych romajskich oligarchów czy bułgarskich klientów cesarskiego domu (vestarcha Nestor) ${ }^{28}$.

Zgoła odmiennie cesarz postąpił obsadzając godności kościelne, co jest widoczne w wypadku rezydującego w Ochrydzie arcybiskupa, najważniejszego hierarchy na ziemiach bułgarskich do końca XII w. Zagwarantowany przywilejami Bazylego II stan posiadania tutejszego Kościoła jest lepiej udokumentowany niż w innych krajach

24 Й. Иванов, Български старини из Македония, dz. суt., s. 550; Sigiliony cesarza Bazylego II, w: Testimonia, z. 4, s. 107. Zob. А. Добычина, „Под одним ярмом” с Византией, dz. суt., s. 478-479.

25 Ioan. Scylitz., s. 359 16-18. Oprócz pewnej liczby sztuk złota złożyły się nań również insygnia (perłowe korony i szaty ze złotogłowiu) ostatnich carów. O symbolicznej randze bułgarskich regaliów może świadczyć użycie ich starszych odpowiedników (złota korona, purpurowa tiara i obuwie) w ceremonii konstantynopolitańskiego triumfu Jana Tzymiskesa w 972 r. Tamże, s. 310 65-66.

26 љ. Максимовиђ, Организация византийске власти у новоосвојеним областима после 1018. гоине, ЗРВИ, 36, 1997, s. 38-42; В. Krsmanović, The Byzantine Province in Change (On the Treshold Between the $10^{\text {th }}$ and $11^{\text {th }}$ Century, dz. cyt, s. 191-203; B. Petrovski, Central-southern Europe under the restored Byzantine administration after the fall of Samuel state, w: Европейският Югоизток, dz. суt., s. 266-276.

27 J.-C. Cheynet, Les généraux byzantins face aux Bulgares au temps de Basile II et le destin de leurs familles, w: Европейският Югоизток, dz. суt., 344-365: np. Dawid Arianites, Konstantyn Diogenes, Tzotzikios, Andronik Dukas, Niketas Pegonites, Eustacjusz Dafnomyles. Ostatni z nich, jak pisał Skylitzes (s. 362 19-23) w rozmowie z Bułgarami ostentacyjnie podkreślał brak swoich powiązań z bałkańską częścią Cesarstwa. Jak zauważa Cheynet (s. 347-348) wśród nominowanych notabli wyraźnie zabrakło przedstawicieli starych rodów arystokratycznych z Anatolii (Fokasów, Sklerosów, Kurkuasów, Malejnosów) buntujących się przeciwko Bazylemu II w przedostatniej dekadzie X w.

${ }^{28}$ J.-C. Cheynet, Dévaluation des dignités et devaluation monétaire dans la second moitié du XIe siècle, "Byzantion”, 53, 1983, s. 465, por. J. Dudek, ,, Cała ziemia dyrracheńska” pod panowaniem bizantyńskim w latach 1005 w latach 1005-1205, Zielona Góra 1999, s. 158-165. 
Europy słowiańskiej ${ }^{29}$. Niezależnie od różnych hipotez związanych z genezą arcybiskupstwa ochrydzkiego, majątek Kościoła Bułgarii był jednym z czynników gwarantujących jego status w średniowieczu ${ }^{30}$. Bezpośrednio po podboju Bazyli II wyznaczył arcybiskupem mnicha Jana z Debaru, ihumena klasztoru św. Bogurodzicy, który utrzymał swój urząd dożywotnio do $1036 \mathrm{r}$. O podległych mu biskupach nie zachowały się żadne dane, zapewne również pochodzili z miejscowego duchowieństwa. Jana zastąpił pochodzący ze wschodu Leon, protegowany rodu paflagońskiego. Jego nominacja stworzyła wyraźny precedens, rodowód kolejnych jedenastowiecznych arcybiskupów (Teodul, Jan Lampenos, Jan Aoinos, Teofilakt) oraz znanych z imienia biskupów (np. Michał i Nicefor w Sofii, Teodozjusz w Dewolu) sugeruje zanik duchownych pochodzenia bułgarskiego w tym kręgu ${ }^{31}$.

Charakterystykę świeckich elit Bułgarii w 1018 r. należy rozpocząć od jej członów: rodu panującego, dygnitarzy i drużyny. W pierwszej kolejności należy wyjaśnić statusu Komitopulów, nowej bułgarskiej dynastii od schyłku X w. Grecki termin

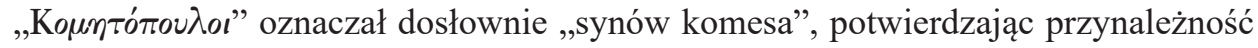
czterech braci: Samuela, Aarona, Mojżesza i Dawida do elity. ${ }^{32}$ Tytuł „komesa” (łac. comes, gr. кóuns, słow. коннтт) wymieniają źródła z IX-X w. dla określenia namiestników dużych prowincji, w pewnym okresie cała Bułgaria składała się co najmniej z dziesięciu takich jednostek administracyjnych. Upowszechnienie się takiego tytułu

\footnotetext{
${ }^{29} \mathrm{~W}$ cesarskim przywileju arcybiskupom Bułgarii oraz ich eparchom zapewniono stan posiadania z czasów „starych władców” tj. Piotra I oraz Samuela. Skrupulatnie wyliczono ich rozsiane po ziemiach bułgarskich majętności w postaci półtora tysiąca chłopskich zagród, pozostałe środki materialne będące w ich posiadaniu nie zostały już wymienione, z pewnością były pokaźne. Trudno jednak oszacować majątek Kościoła bułgarskiego sprzed 1018 r., z tamtych czasów nie zachowało się żadne świadectwo porównywalne z sigilionami Bazylego II. Uwzględniając skalę środków przeznaczonych na budowę i utrzymanie monumentalnych obiektów sakralnych w Presławiu, Plisce, Ochrydzie, Dewolu, wysoki status biskupów w hierarchii chrześcijańskiej Bułgarii, należy przyjąć, że Symeon Wielki i Piotr I (oraz chrześcijańscy bojarzy) hojnie wspierali rodzimy Kościół. Nagromadzone za ich panowania zasoby pozwoliły bułgarskim hierarchom przetrwać trudny okres w latach 971-992, dokumentowany ich przemieszczeniem do Sofii (Triaditzy), potem Wodeny i Prespy. Zob. Б. Николова, Устройство и управление на българската православна църква (IX-XIV век), София 1997, s. 83-144; И. Божилов, Българската архиепископия XI-XII век, dz. cyt. s. 50-57; M.J. Leszka, K. Marinow, Carstwo butgarskie. Politykaspołeczeństwo - gospodarka - kultura. 866-971, Warszawa 2015, s. 240-256; M.J. Leszka, The Status of the Bulgarian Church and its Organization, w: The Bulgarian State in 927-969, dz. cyt., s. 303-317.

${ }^{30}$ И. Снегаров, История на охридската архиепископия. Том 1. От основаването ѝ до завладяването на Балканския полуостров от туриите, София 1995, s. 3-21. Por. Ioan. Scylitz.,

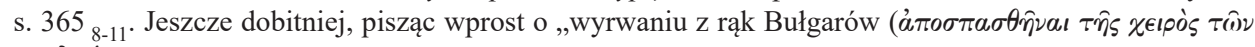

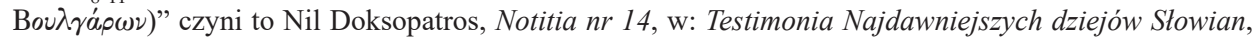
z. 4, seria grecka, red. A. Brzóstkowska, W. Swoboda, Warszawa 1997, s. 66-67. Zob. A. Delikari, Die Situation in Nord-West Makedonien während der Regierung des Basileios II. die sogennante Kirche des Zaren Samuel und die Gründung des Erzbistums von Ochrid, w: Европейският Югоизток, dz. cyt., s. 236-243; V. Tăpkova-Zaimova, The Du Cange Catalogue, dz. cyt., s. 214; И. Божилов, Българската архиепископия XI-XII век. Списъкът на българските архиепископи, София 2011, s. 65-75.

${ }^{31}$ И. Снегаров, История на охридската архиепископия. Том 1, dz. суt., s. 195- 204, 213-214.

32 A. K(azhdan), Kometopouloi, w: ODB, t. 2, s. 1140-1141; PmZ, t. 3, nr 26038, sv. „Nıкó̀aos”
} 
potwierdza proces chrystianizacji. Niewykluczone, że w czasach chanów pierwowzo-

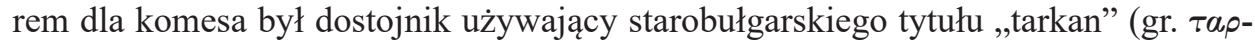

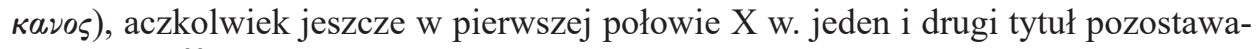
ły w użyciü33.

Synowie Mikołaja zastąpili dynastię, która doszła do władzy nad Bułgarią jeszcze w czasach pogańskich na początku IX w. Po stworzeniu własnego ośrodka władzy na zachodnich peryferiach początkowo faktycznie rządzili odwołując się do autorytetu Symeona Wielkiego i jego następców, dopiero od 996 r. Samuel oficjalnie występuje jako car Bułgarów ${ }^{34}$. Podkreślić należy, że brak przykładów na kontestację legitymizmu Komitopulów przez rodzime elity. Można to próbować tłumaczyć tym, że w pierwszym państwie bułgarskim parokrotnie dochodziło do zmiany rodu panującego, zwłaszcza w VIII w. Odsunięcie od władzy było wówczas rezultatem braku odpowiednich sukcesorów, klęsk militarnych czy bliżej nie sprecyzowanych kryzysów wewnętrznych. Detronizacja chana i jego potomków rodziła napięcia ale nie prowadziła do rozpadu państwa. Dlatego od końca $\mathrm{X}$ w. bułgarscy możni oraz kościelni hierarchowie wspierali monarsze aspiracje Samuela, jego syna (Gabriela Radomira) oraz bratanka (Jana Władysława) sankcjonując polityczną marginalizację żyjących potomków cara Piotra ${ }^{35}$.

Większe problemy rodziła natomiast jedność w nowym rodzie panującym. Dwaj synowie komesa Mikołaja, Dawid, Mojżesz - zginęli z rąk Bizantyńczyków i Wołochów, natomiast Aaron padł ofiarą rodzinnego mordu. W przeprowadzonej przez Samuela masakrze w Rametanicy w czerwcu 987 r. uśmiercono prawie całą rodzinę

33 Т. Славова, Владетел и администрация в ранносредновековна България. Филологически аспекти, София 2010, s. 191-197.

34 Trzonem władzy Komitopulów było dorzecze środkowe i górne dorzecze Wardaru, obszar od pocz. VII w zamieszkały przez mieszaną etnicznie ludność, zdominowaną przez słowiańskie plemiona Brsjaków, Wajunitów i Welegezytów. Zamieszkiwały tam również górskie społeczności Wołochów i Albańczyków. Podbity przez Bułgarów w połowie IX w., odtąd nazywany Kutmiczewicą, prawdopodobnie zarządzany przez komesa, pozostawał jednak do połowy X w. na peryferiach ówczesnej Bułgarii. Zob. S. Rek, Powstanie zachodniobułgarskiego państwa Komitupulów, „Przegląd Historyczny”, 64, 1983, 2 , s. 244-250; W. Swoboda, Kutmičewica, w: SSS, t. 2, s. 571; tegoż, Devol, w: tamże, t. 8, s.36-37; tegoż, Kotokios, w: tamże, t. 8, s. 370; A. K(azhdan), C.M. B(rand), Samuel of Bulgaria, w: ODB, t. 3, s. 1838;

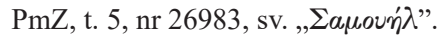

35 Jednym z nich był nim Roman, młodszy brat bezpotomnie zmarłego Borysa II (968-971). Jako eunuch formalnie nie mógł zostać monarchą, aczkolwiek w niektórych opracowaniach występuje jako car Roman I Symeon (977-991). Po ucieczce z niewoli bizantyńskiej osiadł w Skopje, które poddał Bazylemu II w 991 r., potem został bizantyńskim urzędnikiem. Jego usunięcie się z Bułgarii zdaniem niektórych badaczy mogło formalizować rządy Samuela. Zob. Й. Андреев, И. Лазаров, П. Павлов, Кой кой е в средновековна България, София 1994, s. 326; П. Павлов, Бележки за политическата идеология на първото българско царство при иар Самуил и неговите наследники, w: Европейският Югоизток, dz. cyt., s. 199-207; S. Pirivatrić, Personal names in the ruling familie of the First Bulgarian Empire in the second half of $10^{\text {th }}$ and the early $11^{\text {th }}$ centurie. Some observations on their political implications, w: Европейският Югоизток, dz. суt., s. 590-591; PmZ, t.5, 26847, sv. "Рڤнаvós”. 
Aarona $^{36}$. Zapoczątkowało to krwawą i długą wróżdę między Komitopulami. Ocalały z rzezi, jedyny z synów Aarona, Jan (Światosław) Władysław, po latach w 1015 r. zabił Samuelowego syna Gabriela Radomira (1014-1015) i zawłaszczając tron oślepił jednego z jego potomków ${ }^{37}$. Śmierć Jana Władysława pod Dyrrachion wytworzyła wyraźną próżnię polityczną. Jego najstarszy syn Presjan nie posiadał wówczas, zapewne z racji wieku, wystarczającego autorytetu, aby bułgarskie elity uznały go jako sukcesora dziedzictwa Samuela. Wiele na to wskazuje, że jedną z przyczyn kapitulacji przed cesarzem był kryzys przywództwa w państwie Bułgarów. Problem ów, dał znać o sobie ponad dwadzieścia lat później, w czasach powstania Deliana. W początkowej fazie ruchu jednym przywódców powstania został Tichomir, nobil nie pochodzący z rodu Komitopulów i ogłoszony carem Bułgarów przez swoich zwolenników. Jego brutalna eliminacja (poprzez ukamienowanie) na polecenie Deliana nie zapobiegła kolejnym tarciom w gronie bułgarskiej elity ${ }^{38}$. Aluzjan, syn Jan Władysława oślepił Deliana, prowadzonego później ulicami Konstantynopola w tryumfalnym pochodzie cesarza Michała IV. W tych okolicznościach konflikt wśród elity przyczynił się do przyśpieszenia załamania największego powstania Bułgarów w okresie bizantyńskiej niewoli ${ }^{39}$.

O pozostałych bułgarskich nobilach wiadomo już znacznie mniej. W trakcie burzliwych wydarzeń z lat 971-976, wraz z upadkiem dotychczasowego politycznego centrum w Presławiu i Plisce nastąpiły istotne zmiany w ich składzie i strukturze. Przestają być zauważalni dygnitarze, których tytulatura, np. „bojar” ( $\beta o i ̂ a \hat{\varsigma}$ ) wywodziła $\mathrm{z}$ dawnych stepowych tradycji ${ }^{40}$. Pozostał tylko kavchan (каuкávos, o kтaxá $\eta \varsigma)$, który w IX-X w. był jednym z kluczowych dostojników w państwie. Na początku XI w. bułgarscy możni są określani przy użyciu takich tytułów jak: archont

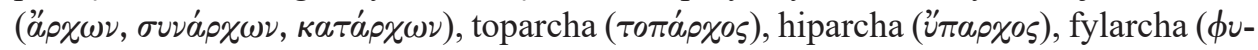

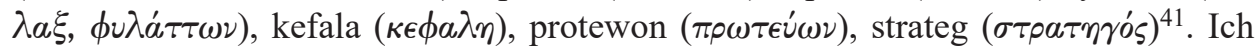
nomenklatura ma zdecydowanie bizantyńską genezę o etymologii sięgającej czasów antycznych. W tym wypadku bizantyńscy autorzy charakteryzując społeczno-

36 И. Илиев, Добавки на епископ Михаил Деволски, dz. cyt. s. 45 [ = Ioan. Scylitz., s. 329 77-91,

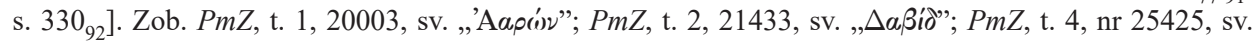

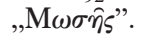

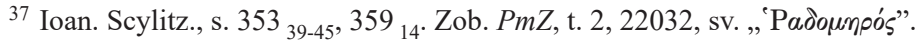

38 Ioan. Scylitz., s. 410-411.

${ }^{39}$ Ioan. Scylitz., s. 414; Michael Psellos, Chronographie IV 49, dz. cyt. s.81. Aluzjan poddał się Bizantyńczykom, zyskując amnestię i cesarską łaskę. Zob. B. Holmes, Basil II and the Governance of Empire, dz. cyt., s. 211-216., przedstawiającej tę kwestię z perspektywy bizantyńskich autorów z drugiej poł. XI w.

${ }^{40}$ Gy. Moravcsik, Byzantinoturcica. II. Sprachreste der Türkvölker in den byzantinischen Quellen, Berlin 1983, s.v. ,ßoî̀ $a \varsigma^{\prime \prime}$, s. 93-94. Termin przetrwa jeszcze w najbliższych stuleciach w niektórych kręgach bizantyńskiej arystokracji na Bałkanach jako jedno z używanych imion rodowych. Zob. И. Божилов, Българите във византийската империя, dz. cyt., s. 255-261.

${ }^{41}$ Ioan. Scylitz., s. 73, 86. Zob. Г.Н. Николов, Централизъм и регионализм, dz. cyt., w zestawie sporządzonym przez autora, s. 158-161. 
ści barbarzyńskie elastycznie dostosowywali używaną przez siebie terminologię do określenia do statusu posiadaczy. Np. za archontów uznawali zarówno urzędników z carskiego otoczenia, jak i niezależnych książąt, naczelników czy przywódców autonomicznych miast ${ }^{42}$.

Cechą elity bułgarskiej w czasach Komitopulów była jej etniczna różnorodność. Ormiańskie pochodzenie przypisywano nawet protoplaście dynastii komesowi Mikołajowi, wskazując na występujące w ormiańskich źródłach określenie jego synów jako „Komsajagk””. Jednak bezspornym wątkiem pozostaje tylko imię małżonki Mikołaja, niejakiej Ripsime (Hripsime), której patronką była jedna ze świętych Kościoła gregoriańskiego (29 IX) ${ }^{43}$. Samuel, syn Mikołaja i faktyczny założyciel dynastii był poprzez małżeństwo z Agatą z Dyrrachion spowinowacony z Chryseliosami, oligarchami z tego strategicznie położonego ośrodka miejskiego ${ }^{44}$. W otoczeniu Samuela dostrzec można postacie spoza kręgu bułgarskich nobilów, czasami dokooptowane przymusowo. Jednym z jego zięciów był Aszot Taronita, bizantyński arystokrata z ormiańskiej rodziny, natomiast drugim był Jan Włodzimierz, książę serbskiej Zety ${ }^{45}$. Obaj byli jeńcami, podobnie jak branka Irena z tesalskiej Larisy, druga żona przyszłego cara Gabriela Radomira ${ }^{46}$. Samuel próbował również pozyskać sojuszników na drodze dynastycznych mariaży z ościennymi władcami, nie przyniosło to jednak poważniejszych rezultatów. Gabriel Radomir swoje pierwsze małżeństwo zawarł ok. 985/986 r. z córką nie sprecyzowanego władcy Węgrów, aby po kilku latach ją wypędzićc ${ }^{47}$. Mimo wrogich relacji z Cesarstwem praktycznie aż do ostatnich lat

42 J.-C. Cheynet, Toparque et topotérètes à la fin du $11^{e}$ siècle, REB, 42, 1984, s. 215-224; M. Angold, Archons and dynasts. Local aristocracies and the cities of the later Byzantine Empire, w: The Byzantine Aristocracy IX to XIII centuries, ed. M. Angold, Oxford 1984, s. 236-253; A. K(azhdan), Strategos, w: $O D B$, t. 3, s. 1964; A. K(azhdan), Toparchus, w: ODB, t. 3, s. 2095; S. Rek, Powstanie zachodniobutgarskiego państwa Komitupulów, dz. cyt., s. 251-253.

${ }^{43}$ И. Илиев, Добавки на епископ Михаил Деволски, dz. cyt., s. 45 [ = Ioan. Scylitz., s. 349]; Й. Иванов, Български старини из Македония, dz. суt. 23-26, s. Zob. PmZ, t. 5, 22633, sv. “'Рı४i uү”. W. Seibt, Untersuchungen zur vor- und Frühgeschichte der ,, bulgarischen” Kometopulen, „Handes Amsorya", 89, 1975, s. 66-100, zwłaszcza 80-88. W kwestii imion kolejnych generacji Komitopulów będących dowodem ich ścisłych relacji z hierarchami bułgarskiego Kościoła na przełomie X-XI w. wypowiada się S. Pirivatrić, Personal names in the ruling familie of the First Bulgarian Empire, dz. cyt., 588594.

${ }^{44}$ И. Илиев, Добавки на епископ Михаил Деволски, dz. cyt., s. 46 [ = Ioan. Scylitz., s. 349 48-51].

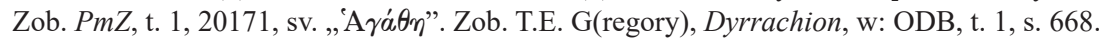

${ }^{45}$ Romantyczne okoliczności zawarcia tych związków identycznie przedstawiają Skylitzes (dz. cyt., s. 341-342) i autor „Latopisu Popa z Dukli”. Zob. Gesta Regum Sclavorum, cap. 36, ed. T. Živković, t. 1,

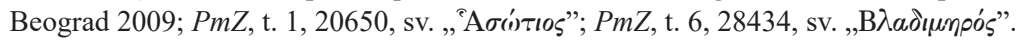

${ }^{46}$ И. Илиев, Добавки на епископ Михаил Деволски, dz. cyt., s. 46, 50, [ = Ioan. Scylitz., s.350 56-58,

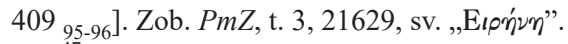

${ }^{47}$ И. Илиев, Добавки на епископ Михаил Деволски, dz. cyt. s. 46, 50, [ = Ioan. Scylitz., s.350 56 ${ }_{57}, 409$ 95-96 $]$. W literaturze przedmiotu dominuje przekonanie, że była to nieznana z imienia córka króla Stefana I Wielkiego (997-1038) czy nawet jego poprzednika Gejzy (970-997). Zob. PmZ, t. 2, 22032A. Kwestionuje to J. Leśny, (Państwo Samuela a jego zachodni sasiedzi, „Balcanica Posnaniensia. Acta et Studia”, 2, 1985, s. 88-92) przedstawiając szereg argumentów przemawiających za tym, że ojcem węgier- 
panowania Komitopulów trwał proces kooptacji do elit bułgarskich cudzoziemców. Oprócz Romajów spowinowaconych z bułgarskim rodem panującym uwzględnić należy również lokalnych notabli, np tesalskich archontów i toparchów, którzy mniej lub bardziej dobrowolnie zgodzili się zostać poddanymi Komitopulów. Podobnie było z jeńcami osadzonymi w centralnej części państwa (między Ochrydą a Prespą) i zobowiązanymi do wojskowej służby ${ }^{48}$.

Skylitzes dostarcza pewnych danych liczbowych odnośnie do rozmiarów elity bułgarskiej. W jednym z kluczowych aktów kapitulacji przed Bazylim II poprzedzającym wkroczenie cesarza do Ochrydy uczestniczyło 35 archontów, każdy z nich zarządzał twierdzą wraz z okalającym ją okręgiem. Przypuszczalnie liczba bułgarskich nobilów włącznie z carską rodziną z uwzględnieniem najbliższych krewnych mogła liczyć ok. 100-150 osób ${ }^{49}$. Mimo stosunkowo świeżej dynastycznej tradycji, etnicznego zróżnicowania i wewnętrznych podziałów nobilowie likwidowanego państwa zostali protoplastami szeregu bułgarsko-bizantyńskich rodów, których wpływy i ranga utrzymały się do podboju osmańskiego. $\mathrm{Z}$ ich grona oprócz bezpośrednich potomków Komitopulów, w literaturze przedmiotu znanych jako Władysławowicze (tj. potomkowie cara Jana Władysława), wywodzili się Nestongowie, Gudeliosi, Glawasowie, Dobromirowie, Kawchanowie, prawdopodobnie również Borilosowie, Boilasi, Boioannesi oraz Bulgarosowie. Ich antenaci kapitulując w 1018 r. otrzymali od autokratora gwarancję nietykalności oraz utrzymania swojego statusu, zapewne stąd tylko nieliczni bułgarscy nobilowie usiłowali podjąć opór ${ }^{50}$. Bazyli II w latach 1018-1025 surowo potraktował Bułgarów, których podejrzewał o zamiar buntu przeciwko jego władzy. Zwykle przypłacali to oślepieniem, konfiskatą majątku i wygnaniem. Podobny los spotkał również niektórych nobilów po 1025 r., dotyczył on jednak tych, których oskarżano o udział w spiskach na tle sukcesji, charakterystycznych dla

skiej księżniczki, był jeden ze wschodniowęgierskich władców pokonanych przez Stefana na przełomie $\mathrm{X}-\mathrm{XI}$ w., w tych okolicznościach sojusz utracił realne znaczenie.

48 Советы и рассказы Кекавмена. Поучение византийского полководиза з ХІ века. Подготовка текста, введение, перевод и комментарий Г.Г. Литаврина. Издание второе, переработанное и дополненное, Санкт Петербург 2003, s. $268_{10-12}$; Ioan. Scylitz., s. $363_{52-56}$. Można mówić o trwałości tej asymilacji, skoro ok. 20 lat po podboju jeden z Chryseliosów w Armenii nadal jest nazywany przez kronikarza Bułgarem. Zob. Ioan. Scylitz., s. $388_{38}$.

${ }^{49}$ Tożsamość większości znanych nam bułgarskich arystokratów dotyczy członków rodu panującego (caryca Maria, Presjan, Aluzjan, Aaron, Trajan, Radomir, Klemens). W wypadku nobilów spoza rodu Komitopulów, którzy uczestniczyli w kapitulacji w 1018 r., to znamy imionia 12 (Krakras, Bogdan, Dragomouzos, Nikolitzas, Nestoritzes, Lazarites, Dobromir, Achtum, Iwatzes, Elemag, Sermon, Gabras), co daje sporą liczbę na tle innych słowiańskich państw. Wyjątkiem może być otoczenie władcy Rusów Igora, którego porozumienie z cesarzem Romanem I Lekapenosem w grudniu 944 r. co po stronie ruskiej miało poświadczyć swoimi imionami 50 przywódców różnej rangi. Zob. Regesten der Kaiserukunden des oströmischen Reiches von 565-1453, 1. Teil, 2. Halband, 867-1025, bearbeitet von F. Dölger, A.E. Müller, A. Beihammer, München 2003, nr 647.

${ }^{50}$ И. Божилов, Българите във византийската империя, dz. суt., s. 72, 229-234, 236-276, 278305, 336-346. Następna tak widoczna grupa rodzin bułgarskich notabli pojawia się w Bizancjum dopiero po 1186 r. za sprawą Asenidów i ich politycznej klienteli. 
ostatnich pokoleń władców dynastii macedońskiej. Zdecydowana większość nobilów zachowywała jednak swój status ustalony przez zdobywcę Bułgarii w 1018 roku $^{51}$.

Po 22 latach dojdzie jednak do wielkiego wybuchu niezadowolenia Bułgarów w postaci powstania Deliana. Najwięcej informacji o tych wydarzeniach, które przybrały formę regularnej wojny, dostarcza Skylitzes. Opis wojny z Bułgarami jest umieszczony w końcowej partii rozdziału poświeconego rządom cesarza Michała IV Paflagończyka, do powstania doszło bowiem po sześciu latach jego rządów w letnich miesiącach $1040 \mathrm{r}$. Z przekazu kronikarza, potwierdzonego innymi świadectwami wynika, że cesarz nie zważając na ciężką chorobę poświęcił na stłumienie rebelii ostatnie lata swojego życia (zm. 10 XII 1041 r.) (2) $^{52}$ Skylitzes wyjaśniają powody powstania Bułgarów pisze o nadużyciach cesarskich poborców podatkowych. Na kartach jego kroniki pojawia się wyrazisty opis zwykle wykorzystany dla wyjaśnienia początkowego sukcesu Deliana:

Cesarz Bazyli bowiem, gdy podbił Bułgarów, nie zamierzał wprowadzać całkowicie nowego porządku, ani zmieniać praktyki rządzenia, lecz chciał pozostawić ten sam ład i takie zarządzanie, jakie niegdyś określił Samuel. Mianowicie, że każdy Bułgar, który posiada zaprzęg wołów, daje na rzecz państwa jedną miarę (modios) zboża, i tyle samo prosa, jeden dzban (stamnos) wina, natomiast Orfanotrof zarządził, aby zamiast produktów dawano pieniądze. To właśnie miejscowi znosili z trudem, a uznawszy pojawienie się Deleanosa za właściwy moment zrzucili panowanie Rzymian i wrócili do dawnego stylu życia ${ }^{53}$. (Przekł. A. Kotłowska)

Powyższy przekaz uzyskuje potwierdzenie nadal żywymi (oraz oczywiście idealizowanymi) rodzimymi wspomnieniami lat panowania dawnych rodzimych władców ${ }^{54}$. W tych okolicznościach nośne są tezy badaczy, że cesarz i jego bezwzględny minister finansów zerwali z tradycją pobierania od Bułgarów danin w naturze, praktykę utrzymaną przez Bazylego II. Decyzją Orfanotrofa zamiast rocznej poradlnej daniny w jęczmieniu i prosie (ok. 36 l) i winie (ok. 7,5 1) od bułgarskich chłopów zaczęto

51 J.-C. Cheynet, Pouvoir et contestations à Byzance (963-1210), Paris 1990, nr 20 (Elinagos), s. 36, nr 27 (Presjan), s. 39-40; А. Мохов, Командый состав византийской армии в ХІ в. Правление Романа III Аргира (1028-1034), „Античная древость и средние века”, 31, 2000, s. 195.

52 Ioan. Scylitz., s. 409-415; Mich. Psell., IV 39, 40, 41, 42, 43, 44, 45, 46, 47, 48, 49, 50, dz. cyt. t. 1 , s. 76-83. Zob. A. K(azhdan), C.M. B(rand), A. C(utler), Michael IV Paphlagon, w: ODB, t. 2, s. 13651366. Na temat przebiegu powstania zob. Г.Г. Литаврин, Болгария и Византия в XI-XII вв., dz.cyt., s. 376-396.

${ }^{53}$ Ioan. Scylitz., s $412_{68-76}$, Testimonia Najdawniejszych Dziejów Stowian. Seria Grecka, z. 6. Pisarze wieku XI, tłum. i kom. A. Kotłowska, współpraca A. Brzóstkowska, Warszawa 2013, s. 253. Podobnie w kontynuacji jego kroniki. Zob. Hē synécheia tēs Chronografias toú Ioánnou Skylitzē, ed. E. Tsolakes, Thessalonikē 1968, s. 162.

${ }^{54}$ Сказание за светия пророк Исайя за бъдните години и за иарете, и за Антихриста, който ще дойде w: Г. Тапкова-Заимова, А. Милтенова, Историко-апокалиптична книжнина, dz. cyt., s. 151, 156. Pod rządami „błogosławionego” cara Michała (Borysa?) podatki były symboliczne, rocznie od krzewu winorośli miarka wina, od snopka kłos, od owcy kłębek wełny, łyżka miodu lub masła i jedno jajko. Podobnie Български апокрифен летопис, tamże, s. 196; G. Minczew, M. Skowronek, Apokryfy i legendy starotestamentowe Stowian poludniowych, dz. cyt., s. 65. 
ściągać podatki w srebrnej lub złotej monecie. Dotkliwość tej zmiany wynikać miała z ekonomicznego zacofania podbitej Bułgarii. Na jej ziemiach dominowały formy gospodarki naturalnej, co czyniło podatek faktycznie większym z powodu oddalenia wieśniaków od rynków zbytu w nabrzeżnych miastach ${ }^{55}$. Skutkowało to interpretacją powstania jako narodowego i chłopskiego ruchu. W ten sposób zaistniał wizerunek Deliana jako przywódcy ludowego powstania, zaś bułgarskim wielmożom wyznaczono rolę asekurantów, którzy po pierwszych militarnych niepowodzeniach kapitulują przed cesarzem za cenę zachowania swoich przywilejów ${ }^{56}$.

Należy jednak mieć na uwadze, że dla Skylitzesa negatywnym bohaterem tej narracji w pierwszej kolejności pozostaje Jan Orfanotrof. Kronikarz nie szczędzi mu słów krytyki, oskarżając tego dygnitarza o liczne niegodziwości popełnione wobec prostego ludu, zarówno w Syrii i w Bułgarii ${ }^{57}$. Należy też podkreślić, że według kronikarza Jan nadużywał władzy wobec arystokracji. Dotyczy to nie tylko członków lokalnych elit w Bułgarii lub Armenii. Ofiarami jego represji byli również prowincjonalni i konstantynopolitańscy arystokraci ze starych romejskich rodów włącznie z samą cesarzową Zoe ${ }^{58}$.

Jan z pewnością nie był zwyczajnym chciwym i skorumpowanym urzędnikiem, wiadomo że pomiędzy 1034 a 1042 r. był jednym z kluczowych polityków bizantyńskich. Pełnił różne urzędy, jednym z nich był zarząd stołecznego sierocińca

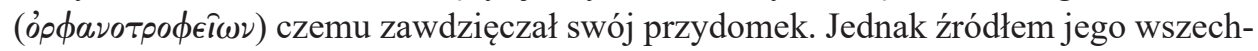
władzy było nieformalne przywództwo nad pochodzącym z Paflagonii cesarskim rodem. Jan będąc eunuchem nie został autokratorem, jednak jego niewątpliwe kwalifikacje administracyjne, talent $\mathrm{i}$ energia w istotny sposób wpływały na funkcjonowanie instytucji państwa w latach 1034-1042. Jeden ze współczesnych autorów donosi, że wprawdzie Orfanotrof to ,eunuch o niskim i podłym pochodzeniu, lecz ogromnie przedsiębiorczy we wszelkiego rodzaju pomysłach"59. Dzięki intrygom Jana jego młodszy brat Michał został cesarzem, zaś pozostałe rodzeństwo i liczni powinowaci

55 Г.Г. Литаврин, Болгария и Византия в XI-XII вв., dz. cyt., s. 315, 350-351; E. Sch(ilbach), A. K(azhdan), Modios, w: $O D B$, t. 2, s. 1388.

56 Np. Г. Г. Литаврин, dz. cyt., s. 395-396.

${ }^{57}$ Ioan. Scylitz., s. 394-397, 412.

58 Ioan. Scylitz., s. 396, 403, 404, 412. Jednym z arystokratów represjonowanych przez Jana był również Aluzjan sprawujący wówczas urząd w Azji Mniejszej, z polecenia ministra nałożono nań grzywnę w 50 funtów złota i skonfiskowano majątek ziemski w temie Charsianon. Podobne sankcje dotknęły również arystokratów ormiańskich zachęconych do osiedlenia w głębi Bizancjum przez Bazylego. Kronikarz Mateusz z Edessy pisze że ormiańscy książęta gnębieni fiskalną polityką Jana przybyli ok. 1040 r. do Konstantynopola na grób Bazylego II, na którym położyli jego chryzobullę z przyznanymi przywilejami, błagając zmarłego cesarza o protekcję. Głęboko poruszony formą protestu cesarz Michał IV polecił bratu, aby respektował dotychczasowe przywileje ormiańskich arystokratów. Trwała wówczas wojna z Bułgarami, co zapewne było zasadniczym powodem cesarskiej łaskawości. Zob. Armenia and the Crusades. Tenth to Twelfth Centuries. The Chronicle of Matthew of Edessa, transl. by A.E. Dosturian, Lanham - New York - London 1993, s. 65.

${ }^{59}$ Mich. Psell., III 18, t. 1, s. $12_{9-10}$, przekł. O. Jurewicz, s. 31. 
otrzymali lukratywne i kluczowe urzędy. Jan faktycznie stworzył i intensywnie umacniał nową dynastię wraz z jej poplecznikami, nierzadko brutalnie odsuwając od władzy i wpływów stare elity. Negatywne opinie o Janie i jego krewniakach powstały po nagłym upadku Paflagończyków wskutek powstania ludu konstantynopolitańskiego w kwietniu 1043 r. Dla ich twórców Orfanotrof uosabiał wady Paflagończyków, w których widziano chciwych bogactw i łapczywych władzy parweniuszy ${ }^{60}$. Zmiany wywołane decyzjami ministra dotknęły bułgarskie elity, aczkolwiek nie musiały one wynikać z negatywnego ustosunkowania ministra do Bułgarów jako takich. Przeciwnie, był jednym z doradców Bazylego II, nie jest wykluczone, że przed 1025 r. mógł mieć wpływ na politykę fiskalną w podbitym kraju ${ }^{61}$.

Czy w takim wypadku poparcie bułgarskich nobilów dla sprawy Deliana mogło wynikać z zarządzeń zmieniającymi dotychczasowe formy ściągania podatków. Szukając wyjaśnienia należy spojrzeć na tę kwestię nieco szerzej. Kekaumen (ok. 1020 - po 1081), naoczny obserwator i uczestnik wojny z Delianem, podkreślał, że dla ludzi z jego warstwy ważne jest posiadanie majątku i piastowanie urzędu. Pierwszą, ów pochodzący z zachodnich Bałkanów arystokrata, określał jako „oikos (oîsos)", termin rozumiany jako dwór zamieszkały przez lokalnego wielmożę wraz z rodziną i służbą, będący środkiem należącej doń majętności ziemskiej oraz patronatu sprawowanego nad sąsiadami niższej rangi społecznej ${ }^{62}$. Posiadanie urzędu i tytułu według Kekaumena to jedna z podstawowych powinności romejskiego arystokraty: „Nie wymawiaj się od pełnienia urzędu i sprawowania obowiązku [...]. Pamiętaj, że tytuł (á $\left.\xi^{\prime} \omega \mu a\right)$ to błogosławieństwo Boże"63. Nie ma powodu wątpić, aby znani mu bułgarscy nobilowie wyznawali przeciwne wartości, mimo utrzymujących się między Bułgarami a Romejami różnic etnicznych i cywilizacyjnych. $Z$ pewnością posiadanie dóbr materialnych z pewnością stanowiło jeden z tych elementów wspólnych dla obu grup notabli. Kekaumen zaznaczając swoją znajomość języka Bułgarów podkreślał, że w ich przekonaniu osobiste bogactwo miało świadczyć o przychylności Bożej ${ }^{64}$.

W kronice Skylitzesa znajdziemy charakterystykę otoczenia jednego z takich wielmożów. Bohater jego opisu to Bułgar Iwatzes, niefortunny kontestator nowego porządku w 1018 r. Po śmierci Jana Władysława zaszył się ze swoją drużyną w trudno dostępnym majątku Pronista w górach nieopodal Dewolu. Z opisu wynika,

${ }^{60}$ R. Janin, Un ministre byzantine: Jean Orphanotrophe (XIe siècle), "Échos d'Orient”, 30, 1931, s. 431-443. Jan utracił wpływy już wcześniej, kiedy został wypędzony z Konstantynopola przez siostrzeńca cesarza Michała V "Kalafatesa” pragnącego zdobyć popularność poprzez pozbycie się niepopularnego ministra.

${ }^{61}$ Mich. Psell., III 18, t. 1, s. $12_{11-12}$.

62 Советы и рассказы Кекавмена, dz. cyt., s. $204_{20-21}, 218_{13-18}, 236_{13,22}$. Zob. Г. Џанкова-Петкова, Югозапднте българските земи през XI в. според “Стратегикона” на Кекавмен, “Известия на Института българската история”, 6, 1956, s. 589-630, zwłaszcza 600-614; P. Magdalino, The Byzantine aristocratic oikos, w: The Byzantine Aristocracy IX to XIII Centuries, ed. M. Angold, Oxford 1984, s. 9293, 95; A.J. C(utler), E.M. J(effreys), Oikos, w: ODB, t. 2, s. 1517-1518;

63 Советы и рассказы Кекавмена, dz. суt., s. $226_{23-24}$.

64 Советы и рассказы Кекавмена, dz. суt., s. 137 26-27. 
że była to rozległa i piękna posiadłość składająca się m.in. z pałacu, kaplicy i ogrodów. Skylitzes pisze, że Iwatzes w czasie świąt gościł sąsiadów, w posiadłości zakwaterowani byli również jego ludzie ${ }^{65}$. Ze słów kronikarza nie wynika jednoznacznie czy posiadłość była własnością Iwatzesa, czy ów wielmoża próbował zawładnąć jednym z dworów Komitpulów. Niewykluczone, że ochoczość innych bułgarskich nobilów do układów z Bazylim II mogła wynikać z gotowości autokratora przekazania im posiadłości w okręgach, którymi uprzednio zarządzali w imieniu ostatniego cara. Nieszczęsny Iwatzes tracąc wzrok i wolność z takiej możliwości nie skorzystał, zaś należące doń dobra ruchome przypadły jego egzekutorowi Eustacjuszowi Dafnomylesowi ${ }^{66}$.

Innym potwierdzeniem prestiżu arystokraty był sprawowany urząd (á $\xi_{\imath} a_{\iota}$ dià

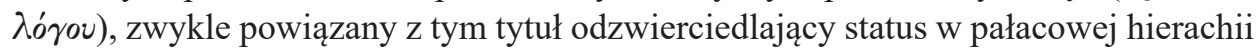

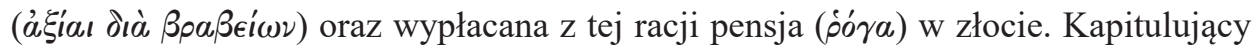
przed Bazylim II carewicz Presjan został uhonorowany godnością magistra (magistros), wdowa po ostatnim carze otrzymała jedyny w bizantyńskiej hierarchii rang

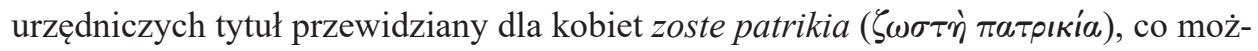
na próbować tłumaczyć jako ,patrycjuszka pasa”, natomiast grupie bułgarskich arystokratów nadano godność patrycjusza (patrikios)" ${ }^{\text {"67. }}$.

Od bułgarskich notabli cesarz domagał się nie tylko wierności, ale również służby. Z uwagi na bałkańskie realia, w wypadku mężczyzn, była to przede wszystkim powinność wojskowa. Już w chwili kapitulacji możni przekazywali cesarzowi nie tylko grody, ale również swoich wojowników, których niezwłocznie dołączano do bizantyńskiej armii. Wraz ze swoimi dowódcami uczestniczyli w kolejnych wojnach prowadzonych przez Bazylego II na różnych granicach Bizancjum ${ }^{68}$. Mobilność Bułgarów

${ }^{65}$ Ioan. Scylitz., s. 360-361.

${ }^{66}$ Ioan. Scylitz., s. 363 38-42. Materialne pozostałości podobnej włości lokalnego notabla, odkryto na równinie Vrina pod Butrinto w obecnej południowej Albanii i są one od 2002 r. przedmiotem systematycznych badań archeologicznych. Pozwoliły one na zidentyfikowanie obiektu złożonego z okazałych jak na miejscowe warunki budynków mieszkalnych połączonych z kaplicą oraz cmentarza. Całość otaczały pomieszczenia dla służby, warsztaty, magazyny. Mieszkańcy wyraźnie zaliczali się do lokalnej elity, wskazują na to materialne znaleziska w postaci bizantyńskich monet z IX-X w., enkolpiony, fragmenty szkła i ceramiki. Zespół budynków na nizinie Vrina mógł przez kilka wieków pozostawać rezydencją archonta w imieniu cesarza zarządzającego okręgiem Wagenecji (dawnym terytorium plemiennym słowiańskich Wajunitów), zamieszkujących wcześniej pas wybrzeża na pograniczu dzisiejszej Albanii i Grecji. Zob. S. Greenslade, R. Hodges, The aristocratic ,oikos” on the Vrina Plan, Butrint c. AD 830-1200, „Byzantine and Modern Greek Studies”, 37, 2013, 1, s. 1-19.

${ }^{67}$ Ioan. Scylitz., s. $357_{67}, 358_{80}, 360_{44-46}, 364_{64}$. Presjan otrzymał od Bazylego II identyczny tytuł jak prawie pół wieku wcześniej zdetronizowany przez Jana Tzymiskesa car Borys II, tamże, s. 310 ${ }_{68-69}$ PmZ, t. 5, nr 26775, sv. „Проvбiávos".

${ }^{68}$ Uhonorowany tytułem protospathariosa Nikulitzes poddał cesarzowi doborową część dawnej drużyny Samuela, podobnie uczynili przyprowadzając swoje przyboczne drużyny (tagmata) hojnie wynagrodzeni przez Bazylego trzej inni naczelnicy: Nestoritzes, Lazarites, Dobromir (Ioan. Scylitz., s. 358 $84-85$, $359_{30-31}$ ). Bezpośrednio po podboju, jak donosi ormiański dziejopis Aristakes z Łastiwertu, wodzowie bułgarscy zostali wysłani na wojnę w Armenii. Zob. Повествование вардапета Аристакеса Ластиверичи 
sugeruje że w służbie bizantyńskiej wykorzystywano ich jako kawalerzystów, m.in.

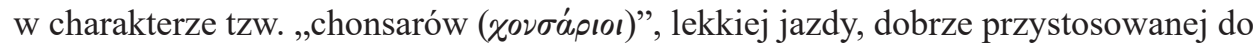
operacji zwiadowczych w niedostępnych terenach górskich. W armii bizantyńskiej również oni zaliczali się do kluczowych formacji kawaleryjskich, ranga ich dowódców musiała być znaczna ${ }^{69}$.

Kekaumen charakteryzując jednego z nobilów bułgarskich posłużył się terminem o słowiańskiej genezie: „wiedz, że strateg w języku bułgarskim nazywa się tzelníkos

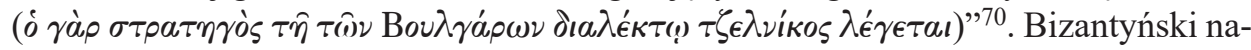
miestnik Dyrrachion na przełomie czwartej i piątej dekady XI w. dowodził wojskiem złożonym głównie z Bułgarów, pod jego komendą znajdowało się wówczas co najmniej siedmiu niższej rangi strategów, których można utożsamiać z takimi „naczelnikami"71. Podlegały im mniejsze okręgi określane w XI w. jako „temy”. Ich dokładna liczba na obszarze dawnego państwa bułgarskiego jest trudna do ustalenia, w $1018 \mathrm{r}$. mogło ich, jak sugeruje G. Nikołow ok. $50^{72}$. Pozostający na ich służbie wojownicy, nawet jeśli zajmowali się również rolnictwem, to ich status społeczny wyższy niż zwykłych rolników. Autorzy bizantyńscy określając takich wojowników korzystali zwykle z terminów „strateía ( $\sigma \tau \rho a \tau \epsilon i a)$ ” „stratioci” ( $\sigma \tau \rho a \tau \iota \dot{\omega} \tau \eta \varsigma)$. Pierwszy z nich, będąc synonimem łacińskiego określenia „militia” oznaczał powinność wojskową, z której samego świadczenia wynikał odpowiedni status społeczny. Drugi stosowano na oznaczenie żołnierzy w sensie ogólnym, mimo że w opracowaniach poświęconych wojskowej i społecznej historii Bizancjum pojęcie stratiotów stosowano dla określenia do grupy chłopów-żołnierzy. Tymczasem Bizantyńczycy określali tym terminem wszystkich żołnierzy służących cesarzowi niezależnie od tego czy byli to rolnicy, najemnicy czy arystokraci ${ }^{73}$.

Ci bułgarscy nobilowie, których tożsamość jest nam znana i czynnie wsparli powstanie Deliana byli wojskowymi ${ }^{74}$. Zdecydowali się udzielić wsparcia pre-

ks. I, перевод с древнеармянского, вступителная статя, коментарий и приложения К.Н. Юзбашяна, Москва 1968, s. 57-58. W ostatnim roku swojego panowania Bazyli II wykorzystał Bułgarów planując wyprawę na Sycylię. Zob. Annales Barensis, a. 1027, w: MGH SS, t. 5, ed. D. Pertz, Hanover 1844, s. 53.

${ }^{69}$ Советы и рассказы Кекавмена, dz. cyt., s. $150_{9-18}$, 168, 192, przyp. nr 94.

${ }^{70}$ Советы и рассказы Кекавмена, dz. суt., s. $188_{30-31}$.

${ }^{71}$ Ioan. Scylitz., $425_{92}$.

72 Г.Н. Николов, Централизъм и регионализм, dz. cyt., s. 202-206. Najobfitsze dane odnoszące się do takich okręgów, ich zarządców, relacji z bizantyńskimi gubernatorami zachowało się z czasów późniejszych, tj. z XII-XIV w. Są określane takimi terminami jak „episkepsis”, „kastron” „,archontia”, „provintia', „chartularat”, „katepanikion”. W zalążkowej formie mogły istnieć już w pierwszych dekadach po podboju. Zob. T. Wasilewski, Administracja bizantyńska na ziemiach stowiańskich i jej polityka wobec Slowian w XI-XII w., „Kwartalnik Historyczny”, 70, 1963, 2, s. 303-321.

${ }^{73}$ E. M(cGeer), A. K(azhdan), Strateia, w: ODB, t. 3, s. 1965; A. K(azhdan), E. M(cGeer), Stratiotes, w: ODB, t. 3, s. 1965-1966.

${ }^{74}$ Zalicza się do nich również Aluzjan. Zob. PmZ, t. 1, nr 20263, sv. „AA Litowoj z Dewolu (Litoboes 101: http://pbw2016.kdl.kcl.ac.uk/ pobranie 17.11.2018) Tichomir (Tichomir 101: http://pbw2016.kdl.kcl.ac.uk/ pobranie 17.11.2018), Antymos (Anthimos 101: http://pbw2016.kdl. 
tendentowi, wprawdzie bezpośredniemu potomkowi Samuela, ale człowiekowi o tajemniczej przeszłości, w jakimś stopniu dynastycznemu outsiderowi. Delian do 1040 r. przebywał poza ziemiami bułgarskimi, prawdopodobnie na obszarze południowo-wschodnich Węgrzech ${ }^{75}$. Zainicjował powstanie przeciwko panowaniu Bizantyńczykom odwołując się do tradycji, zarówno bliższej i jak dalszej. Dwoistość w kreacji jego wizerunku można zauważyć w źródłach bizantyńskich i rodzimych. W pierwszym wypadku Delian występując carskie imię Piotra wyraźnie nawiązał do ożywającej popularności starej dynastii ${ }^{76}$. Natomiast w starobułgarskiej interpolacji do „Opowieści Izajasza” oraz w „Bułgarskim latopisie apokryficznym” został opisany jako „car imieniem Gagan, nazywany Odelianem”, co sugeruje użycie przez pretendenta starego tytułu kagana, wywodzącego się jeszcze z tradycji politycznych Wielkiego Stepu ${ }^{77}$. Pamiętać jednak należy, że twórcy tych tekstów, prawdopodobnie mnisi, w żadnym ze swoich tekstów nie poddawali w wątpliwość chrześcijańskiej konfesji „Gagana Odeljana”. Przeciwnie, był walecznym mężem, walczącym za wiarę, troszczącym się o pomyślność swoich współbraci i ginącym ostatecznie z rąk pogan (Izmaelitów). Również bizantyńscy autorzy nie stawiali Delianowi zarzutu prześladowania chrześcijan. W tych okolicznościach żadnym wypadku powstania Bułgarów z 1040-1041 r. nie można porównać do zbliżonych chronologicznie pogań-

kcl.ac.uk/ pobranie 17.11.2018) oraz Manuel Iwatzes (Manuel 102: http://pbw2016.kdl.kcl.ac.uk/ pobranie 17.11.2018). Ostatni z wymienionych wielmożów był prawdopodobnie spokrewniony z Iwatzesem, który bezskutecznie próbował stawić opór w 1018 r. Рor. Й. Андреев, И. Лазаров, П. Павлов, Кой е кой в средновековна България. Исторически справочник, dz. суt., s. 22, 242-243, 250-251, 381-382.

75 Rebelię zainicjowano w Belgradzie, akces w pierwszej kolejności zgłosili nobilowie z północnych i centralnych regionów dawnego państwa Komitopulów. Zob. Ioan. Scylitz., 409 90-91. O biografii Deliana pisze szerzej Michał Psellos (IV 40, t. 1, s.76 5 ) określając go jako zbiegłego z Konstantynopola sługę i sa-

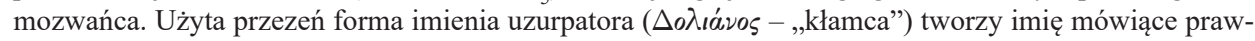
dopodobnie dla celów propagandy. Dewolski biskup ograniczył się do przypomnienia finału pierwszego małżeństwa Gabriela Radomira, który wypędził ciężarną żonę. Brak również potwierdzenia obecności Deliana w Bułgarii przed 1018 r. Zob. И. Илиев, Добавки на епископ Михаил Деволски, dz. суt., s. 50, [= Ioan. Scylitz., $409_{95-96}$ ]. W kwestii literatury poświęconej Delianowi zob. Testimonia, z. 6 s. 24, przyp. $\mathrm{nr} 7$.

${ }^{76}$ M. Kaymakamova, The Cult of the Bulgarian Tsar Peter (927-969) and the Driving Idea of the Bulgarian Liberation Uprising against the Byzantine Rule in the $11^{\text {th }}-12^{\text {th }}$ Century, w: The Bulgarian State in 927-969, dz. cyt., s. 468-473.

77 Сказание Исайево w: Г. Тапкова-Заимова, А. Милтенова, Историко-апокалиптична книжнина, dz. cyt., s. 150, 155; G. Minczew, M. Skowronek, Apokryfy i legendy starotestamentowe Stowian południowych, dz. cyt., s. 68. Zdaniem niektórych badaczy w wypadku powstania Deliana można mówić o pewnej nostalgii za stepowymi tradycjami, w niektórych wypadkach powiązaną z pogaństwem przeżywającym odrodzenie na Węgrzech po 1038 r. Zob. Ts. Stepanov, From „steppe” to Christian empire and back: Bulgaria between 800 and 1100, w: The Other Europe in the Middle Ages. Avars, Bulgars, Khazars, and Cumans, To the memory of Petre Diaconu (1927-2007), ed. F. Curta with the assistance of R. Kovalev, Leiden-Boston 2008, s. 364-367, 374-375; Dz. Madjarov, L'histoire de Petãr (Pierre) Deljan - souverain legitime et du prince Arpad-dûla. Relations entre le ritual et la titulature, "Bulgarian Historical Review", 1, 2011, 1-2, s. 3-40. 
skich reakcji w Polsce i na Węgrzech ${ }^{78}$. Według świadectwa Skylitzesa celem rebe-

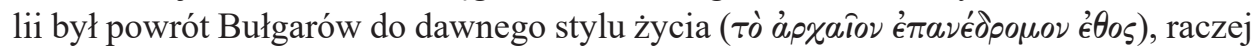
utożsamianego z Komitopulami niż odległym czasem panowania pogańskich chanów. Pod powstańczym sztandarem mogli się zgromadzić Bułgarzy posługującymi się różnymi hasłami związanymi z ideą odbudowy własnej monarchii. Zaliczać się mógł do nich zarówno radykalny opór przed opresyjnym fiskalizmem Orfanotrofa ${ }^{79}$ lub powrót do tradycji przysparzających łupów wypadów na Romanię sprzed 1018 r. ${ }^{80}$ Ostatni z tych czynników, powiązany z militarną profesją nobilów, mógł bezpośrednio wpłynąć na ich postawę w pierwszej fazie powstania Deliana. Jak relacjonuje Skylitzes, Michał Dermokajta będący dowódcą zmobilizowanych do walki z buntem stratiotów z namiestnictwa dyrracheńskiego spróbował pozbawić ich koni, uzbrojenia

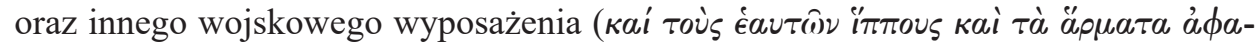

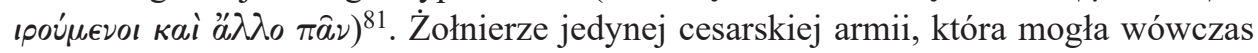
zahamować postępy Deliana, wypowiedzieli posłuszeństwo Dermokajcie, proklamując jednocześnie carem Bułgarów jednego ze swoich dowódców - Tichomira. Ich decyzja, w tej fazie wojny, nie wynikała z lojalności wobec Komitopulów, nowy pretendent nie należał do dynastii. Wytknął mu to wkrótce Delian, który rozkazał uśmiercić Tichomira przez ukamieniowanie ${ }^{82}$. Z wymienionych przez kronikarza dóbr których utrata groziła bułgarskim wojownikom, konie raczej się nie zaliczały do wyposażenia zwykłych chłopów-żołnierzy. W ówczesnej Europie (poza pasem stepów) posiadanie koni i wykorzystanie ich na wojnie było wyznacznikiem przynależności do elity ${ }^{83}$. Nierozważna decyzja Dermokajty była więc iskrą, która spowodowała bunt możnych. Dopatrywać się w niej trzeba nie przykładu nadużyć podyktowanych chęcią wzbogacenia się, co raczej niefortunnej próby rozbrojenia możnych Bułgarów, który utracili zaufanie cesarskiego namiestnika.

Bułgarscy nobilowie z namiestnictwa dyrracheńskiego musieli obawiać się takich decyzji, skoro zdecydowali się na bunt oferując carską koronę jednemu ze swojego grona. Dowodów ich obaw przed zagrożeniem deklasacją można próbować się doszu-

78 Сказание Исайево w: Г. Тапкова-Заимова, А. Милтенова, Историко-апокалиптична книжнинa, dz. cyt., s. 150-151, 155-156. Zob. A. Miltenova, M. Kaimakamova, The Uprising of Petar Deljan (1040-1041) in a new Old Bulgarian Source, "Byzantinobulgarica", 8, 1986, s. 227-240.

79 Ioan. Scylitz., s. $411_{58-62}$.

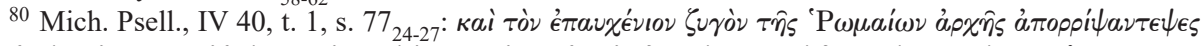

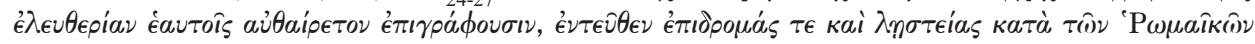

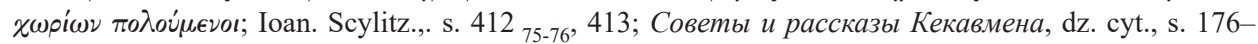
178, 188-190; Miguel Ataliates, Historia, ed. In. Pérez Martín, Madrid 2002, s. 7-8. W połowie XI w. na Bałkanach utrzymał się podział na dawne ziemie bułgarskie i ,stare” prowincje Cesarstwa zdominowane przez Romajów. Zob. J. Bonarek, Romajowie i obcy w kronice Jana Skylitzesa, dz. cyt. s. 92-93.

${ }^{81}$ Ioan. Scylitz., s. 410 17-18.

82 Ioan. Scylitz., s. 410-411.

${ }^{83}$ A. K(azhdan), J.W. N(esbitt), Horses, w: $O D B$, t. 2, s. 948; E.M(cGeer), A. C(utler), Armor, w: ODB, t. 1, s. 182-183; M. Wojnowski, Konnica w armii Cesarstwa Bizantyńskiego od VIII do XIII w. Rola militarna i znaczenie społeczne, Oświęcim 2014, s. 205-215. 
kiwać w reformach wojskowych przeprowadzanych od kilku lat na dunajskiej granicy Bizancjum, której po śmierci Bazylego II zagrażają Pieczyngowie. Ci tureccy stepowcy wypierani ze swoich siedzib na stepach nadczarnomorskich przez wschodnich sąsiadów przeprowadzili w latach 1027-1036 serię najazdów na ziemie bizantyńskie. Ostatnie z nich były szczególnie niszczycielskie, zdewastowane zostały obszary namiestnictwa Paristrionu położonego wzdłuż dolnego Dunaju aż po góry Starej Płaniny, miejscową ludność zmuszono do ucieczki, wzięto do niewoli lub wymordowano ${ }^{84}$. Szkody spowodowane przez koczowników sygnalizowały niewydolność dotychczasowego systemu obrony opartego na miejscowych bułgarskich elitach i potrzebę zreformowania obrony pogranicza dunajskiego. W latach 30-tych XI w. wybudowano liczne forty i twierdze, niektóre z nich obsadzano garnizonami złożonymi z najemników, nierzadko pochodzących spoza Bałkanów. Reformy wojskowe na pograniczu musiały być bardzo kosztowne, załogi pogranicznych fortec należało zaopatrzyć w żywność, wyposażenie wojskowe, zaś żołnierzom płacić regularny żołd. Część z tych środków zapewne dostarczano z centralnego skarbca w Konstantynopolu, większość obciążeń spoczęła jednak na barkach miejscowej ludności. Znaleziska archeologiczne w postaci szeregu numizmatów emitowanych w pierwszej połowie XI w. w szeregu osadach i fortach położonych wzdłuż Dunaju wskazują na tendencję wzrostu znaczenia monet w lokalnym życiu gospodarczym. W dużej mierze jest to rezultat ożywienia handlu naddunajskich emporiów, jak i wynik obecności posługujących się gotówką oddziałów najemnych ${ }^{85}$. W Paristrionie $\mathrm{z}$ tego powodu nie doszło do marginalizacji statusu rodzimych elit, to jednak ich wpływ na zachowania miejscowej społeczność były mniejsze niż na zachodnich Bałkanach. Nieprzypadkowo nie zachowały się żadne informacje o przystąpieniu mieszkańców Paristrionu do powstania Deliana. Miejscowe garnizony utrzymały kontrolę nad newralgicznym pograniczu, aczkolwiek ich żołnierze nie brali udziału w wojnie z Bułgarami. Ciężar stłumienia powstania spoczął na armii osobiście dowodzonej przez cesarza, wykorzystującej jako zaplecze Tesalonikę i Mosynopolis.

Zmiany zainicjowane w Paristrionie mogły sygnalizować bułgarskiej arystokracji niebezpieczeństwo podważenia jej statusu w strukturach militarnych, w dalszej perspektywie marginalizacji przywództwa nad lokalnymi społecznościami. Reakcja cesarza i Jana Orfanotrofa była stosunkowo szybka. Nie ograniczała się do tylko do działań wojskowych, próbowano porozumieć się również z Bułgarami. Symboliczna wydaje się tutaj rola, jaką odegrał w upadku powstania carewicz Aluzjan. Drugi z synów Jana Władysława, po oślepieniu Presjana i zamknięciu w klasztorze carycy Marii urasta do rangi nieformalnego przywódcy Władysławowiczów. Szybkie zakończenie wojny po oślepieniu Deliana i ucieczce Aluzjana prawdopodobnie było efektem po-

\footnotetext{
${ }^{84}$ A. Paroń, Pieczyngowie. Koczownicy w krajobrazie politycznym i kulturowym średniowiecznej Europy, Wrocław 2015, s. 368-370.

85 P. Stephenson, Byzantine Policy towards Paristrion in the mild-eleventh: another interpretation, „Byzantine and Modern Greek Studies”, 22, 1999, s. 43-66.
} 
wstrzymania lub osłabienia tempa tych zmian przez władze bizantyńskie. Represje wobec elit bułgarskich po upadku powstania miały ograniczoną skalę. Michał IV i Jan Orfanotrof zdecydowali się na okazanie łaski buntownikom w szerszym zakresie niż uczynił to Bazyli II po podboju. Bezpośrednio ucierpieli tylko dwaj znani z imienia przywódców, większość bułgarskiej elity wyszła bez szwanku, jej status został zagwarantowany ${ }^{86}$. Nienaruszalność stanu posiadania majątkowego, utrzymanie porządku lokalnej hierarchii wydają się być granicami nieprzekraczalnymi przez cesarskich urzędników ${ }^{87}$. Brak różnic religijnych już wcześniej otworzył drogę do związków Komitopulów z arystokracją romejską, co stopniowo zacznie się uwidaczniać. W połowie XI stulecia bardziej zauważalni od Presjana i Aluzjana staną się inni, młodsi potomkowie Jana Władysława. Jego syn Aaron będzie naczelnym dowódcą armii cesarza Michała VI Bringasa (1056-1057), zaś córka Katarzyna jako małżonka Izaaka I Komnena (1057-1059) zostanie bizantyńską cesarzową. Te awanse i mariaże poświadczają o postępach procesu bizantynizacji najwyższego kręgu elity dawnej Bułgarii. W wymiarze lokalnym potwierdzenie tego procesu można dostrzec zwłaszcza na zachodnich Bałkanach. Zapewne z tych względów kolejne wystąpienie Bułgarów przeciwko rządom bizantyńskim w 1073 r. nie przybrało takich rozmiarów jak powstanie Deliana.

\section{SKRÓTY}

$\mathrm{CFH}$ - Corpus Fontium Historiae Byzantinae

ODB - The Oxford Dictionary of Byzantium, ed. A. Kazhdan i inni, t. 1-3, New York - Oxford 1991.

PmZ - Prosopographie der mittelbyzantinischen Zeit. Zweite Abteilung (867-1025), red. F. Winkelmann, Berlin 2013.

SSS - Stownik starożytności stowiańskich. Encyklopedyczny zarys kultury Stowian o czasów najdawniejszych do schytku wieku XII, red. W. Kowalenko, G. Labuda, T. Lehr-Spławiński, Wrocław-Warszawa-Kraków 1961-1982.

\footnotetext{
${ }^{86}$ Oślepionego Deliana oraz Manuela Iwatzesa prowadzono ulicami Konstantynopola w tryumfalnym pochodzie cesarza Michała IV pod koniec $1041 \mathrm{r}$. Drugi z bułgarskich notabli, podobnie jak jego krewniak w 1018 r. nie chciał złożyć broni po upadku powstania. Dlatego prawdopodobnie nie objęła go cesarska amnestia. Są to jedyni wymienieni z imienia przywódcy powstania, którzy pozostali w niewoli. Ich późniejsze losy są nieznane. Zob. Ioan. Scylitz., s. $414_{45-47}$.

${ }^{87}$ Ustępstwa Bizantyńczyków w 1041 r. raczej nie objęły nowego sposobu ściągania podatków w gotówce. Monetaryzacja gospodarki bałkańskiej rozpoczęta jeszcze w IX stuleciu wyraźnie przyśpieszyła w jedenastym stuleciu. Powstanie Deliana nie zahamowało tego procesu. Przebiegał on stosunkowo szybko na terenach zurbanizowanych, wolniej na obszarach wiejskich pokrywających się z terytorium dawnego państwa bułgarskiego. Nawet tutaj, ćwierć wieku później wołoscy naczelnicy będą od swoich stad wypasanych na górskich połoninach płacić podatki w monecie. Zob. Советы и рассказы Кекавмена, dz. cyt., s. 276.
} 


\section{BIBLIOGRAFIA}

\section{Źródla:}

Annales Barensis, w: MGH SS, t. 5, ed. D. Pertz, Hanover 1844.

Povestvovaniie vardapeta Aristakesa Lastiverci, perevod s drievniearmianskogo, vstupitielnaia statia, komientarij i priloženiia K.N. Iuzbašiana, Moskva 1968 [Повествование вардапета Аристакеса Ластиверии, перевод с древнеармянского, вступителная статя, коментарий и приложения К.Н. Юзбашяна, Москва 1968].

Gesta Regum Sclavorum, ed. T. Živković, Beograd 2009.

Ioannis Scylitzae Synopsis historiarum, ed. H. Thurn, CFHB. Series Berolinensis, Berlin - New York 1973.

Hē synecheia tēs Chronographias tou Iōannou Skylitsē (Ioannes Skylitzes Continuatus), ed. Th. Tsolakēs, Thessalonike 1968.

Iliev Ilija, Dobavki na episkop Michail Devolski ot 1118 g. k'em „Istoričeski svod” na Jovan Skilica (XI v.), w: B. Gjuzelev, Izvori na za srednovekovnata istorija Bălgarija (VII-XV v.) v avstrijskite rûkopisni sbirki i archive. Părvi tom. Bălgarski, drugi slavjanski i vizantijski izvori, Sofija 1994, [И. Илиев, Добавки на епископ Михаил Деволски от 1118 г. към „Исторически свод” на Йован Скилица (XI в.), w: В. Гюзелев, Извори за средновековната история България (VII-XVв.) в австрийските ръкописни сбирки и архиви. Първи том. Български, други славянски и византийски извори, София 1994, s. 45-57.]

Ivanov Jordan, Bălgarski starini iz Makedonija, Sofija 1970, [Й. Иванов, Български старини из Македония, София 1970.]

The Chronicle of Matthew of Edessa. Armenia and the Crusades. Tenth to Twelfth Centuries, transl. A.E. Dostourian, Lanham - New York 1993.

Michael Psellos, Chronographie, ou Historie d'un siècle de Byzance (1976), ed. E. Renauld, Paris 1926.

Michał Psellos, Kronika czyli historia jednego stulecia Bizancjum (976-1077), przekł. O. Jurewicz, Wrocław-Warszawa 1985.

Miguel Ataliates, Historia, ed. In. Pérez Martín, Madrid 2002.

Sovety i rasskazy Kekavmena. Poučenije vizantijskogo polkovodca z XI veka. Podgotovka teksta, vvedenije, perevod i kommentarij G.G. Litavrina. Izdanije vtoroje, pererabobotannoje i dopolnennoje, Sankt Petersburg 2003, [Советы и рассказы Кекавмена. Поучение византийского полководиа з XI века. Подготовка текста, введение, перевод и комментарий Г.Г. Литаврина. Издание второе, пе-реработанное и дополненное, Санкт Петербург 2003.]

Tapkova-Zaimova Vasilka, Miltenova Anisava, Istoriko-apokaliptična knižnina văv Vizantija i i v srednovekovna Bălgarija, Sofija 1996, [В. Тапкова-Заимова, А. Милтенова, Историко-апокалиптична книжнина във Византия и в средовековна България, София 1996.]

Minczew G., Skowronek M., Apokryfy i legendy starotestamentowe Stowian poludniowych, Kraków 2006.

Testimonia Najdawniejszych Dziejów Stowian, z. 4, Pisarze z VIII-XII wieku, red. A. Brzóstkowska, W. Swoboda, Warszawa 1997.

Testimonia Najdawniejszych Dziejów Stowian. Seria Grecka, z. 6. Pisarze wieku XI, tłum. i kom. A. Kotłowska, współpraca A. Brzóstkowska, Warszawa 2013.

Yahyă al-Anțăki, Cronache dell'Egitto fătimide e dell'impero bizantino 937-1033, traduzione dall'arabo, introduzione e cura di B. Pirone, Milano 1998.

Ioannis Zonarae, Epitome historiarum libri XIII-XVIII, ed. Th. Büttner-Wobst, t. 3, Bonn 1897.

\section{Literatura:}

Andrejev Jordan, Ivan Lazarov, Plamen Pavolv, Koj koj je v srednovekovna Bălgarija, Sofija 1994, [Й. Андреев, И. Лазаров, П. Павлов, Кой кой е в средновековна България, София 1994.]

Angold Michael, Archons and dynasts. Local aristocracies and the cities of the later Byzantine Empire, w: The Byzantine Aristocracy IX to XIII centuries, ed. M. Angold, Oxford 1984, s. 236-253. 
Bonarek Jacek, Przyczyny $i$ cele bułgarskich wypraw Świętosława a polityka Bizancjum $w$ latach sześćdziesiatych X wieku „Studia Historyczne”, 39, 1996, 3, s. 287-302.

Bonarek Jacek, Romajowie i obcy w kronice Jana Skylitzesa. Identyfikacja etniczna Bizantyńczyków i ich stosunek do obcych w świetle kroniki Jana Skylitzesa, Toruń 2003.

Božilov Ivan, Bălgarite văv vizantijskata imperia, Sofija 1995, [И. Божилов, Българите във византийската империя, София 1995.]

Božilov Ivan, Gjuzelev Boris, Istorija na srednovekovna Bălgarija VII-XIV vek, Sofija 1999, [И. Божилов., Б. Гюзелев, История на средновековна България VII-XIV век, София 1999.]

Božilov Ivan, Bălgarskata archieskopija XI-XII vek. Spisăkt na bălgarskite arciepiskopi, Sofija 2011, [И. Божилов, Българската архиепископия XI-XII век. Списъкът на българските архиеписко$n u$, София 2011.]

Browning Robert, Byzantium and Bulgaria. A Comparative Study across the Early medieval Frontier, London 1975.

Butgaria. Zarys dziejów, red. I. Dymitrow, Warszawa 1986.

Cheynet Jean-Claude, Dévaluation des dignités et devaluation monétaire dans la second moitié du XIe siècle, "Byzantion", 53, 1983, s. 453-477.

Cheynet Jean-Claude, Toparque et topotérètes à la fin du 11e siècle, "Revue des Études Byzantines", 42, 1984, s. 215-224.

Cheynet Jean-Claude, Pouvoir et contestations à Byzance (963-1210), Paris 1990.

Cheynet Jean-Claude, Les généraux byzantins face aux Bulgares au temps de Basile II et le destin de leurs familles, w: Jevropejskiat Jugoiztok prez vtorata polovina na X-načaloto na XI vek. Istorija i kultura, s. 344-365.

Dobyčina Anastasija, ,,Pod odnim jarmom”s Vizantijej: bolgary i bolgarskije zemli v sostave Vizantijskoj imperii (1018-1185), w: Bălgarsko carstvo. Sbornik v čest'na 60-godišnijata na doc. d-r Georgi N. Nikolov, Sofija 2018, [А. Добычина, „Под одним ярмом” с Византией: болгары и болгарские земли в составе Византийской империй (1018-1185), w: Българско ицарство. Сборник в чест на 60-годишнията на дои. д-р Георги Н. Николов, (REGNUM BULGARIAE. Studia in honorem annorum LX Georgii N. Nikolov), отговорен редактор доц. А. Николов, София 2018, s. 476-497.]

Delikari Angeliki, Die Situation in Nord-West Makedonien während der Regierung des Basileios II. die sogennante Kirche des Zaren Samuel und die Gründung des Erzbistums von Ochrid, w: Jevropejskiat Jugoiztok prez vtorata polovina na X-načaloto na XI vek. Istorija i kultura, s. 236-243.

Dudek Jarosław, „Cała ziemia dyrracheńska” pod panowaniem bizantyńskim w latach 1005 w latach 1005-1205, Zielona Góra 1999.

Dudek Jarosław, Cesarz Bazyli II w opiniach średniowiecznych Bułgarów, w: Stereotypy bałkańskie. Księga jubileuszowa Profesor Ilony Czamańskiej, red. J. Paszkiewicz, Z. Pentek, Poznań 2011, s. 62 85.

Ferluga Jadran, John Scylitzes and Michael of Devol, w: tegoż, Byzantium on the Balkans. Studies on the Byzantine Administration and the Southern Slavs from the VII th to the XII ${ }^{\text {th }}$ Centuries, Amsterdam 1976, s. 337-344.

Greenslade Simon, Hodges Richard, The aristocratic ,oikos” on the Vrina Plan, Butrint c. AD 830-1200, „Byzantine and Modern Greek Studies”, 37, 2013, 1, s. 1-19.

Grotowski Piotr Ł., Święci wojownicy w sztuce bizantyńskiej (843-1261), Kraków 2011.

Holmes Barbara, Basil II and the Governance of Empire (976-1025), Oxford 2005.

Jevropejskiat Jugoiztok prez vtorata polovina na X-načaloto na XI vek. Istorija i kultura, Sofija 2015 [Европейският Югоизток през втората половина на X-началото на XI век. История и култура, София 2015.]

Janin Raymond, Un ministre byzantine: Jean Orphanotrophe (XIe siècle), "Échos d'Orient", 30, 1931, s. 431-443.

Ivan Jordanov, Pečati na potomcite na car Ivan Vladislav (1016-1018) v Vizantija, "Arheologija", 1996, $\mathrm{nr}$ 4, s. 7-22, [И. Йорданов, Печати на потомичте на цุар Иван Владислав (1016-1018) в Византии, „Археология”, 1996, nr 4, s. 7-22.] 
Jóźwiak Wojciech, Obraz początku i końca średniowiecznego państwa w butgarskiej powieści historycznej z lat 1874-1989, Poznań 2017.

Kaymakamova Milyana, The Cult of the Bulgarian Tsar Peter (927-969) and the Driving Idea of the Bulgarian Liberation Uprising against the Byzantine Rule in the $11^{\text {th }}-12^{\text {th }}$ Century, w: The Bulgarian State in 927-969, s. 457-478.

Každan Aleksandr P., Socjalnyj sostav gospodvujuščego klassa Vizantii XI-XII vv., Moskva 1974, [А.П. Каждан., Социальный состав господствующего класса Византии XI-XII вв., Москва 1974.]

Krsmanović Bojana, The Byzantine Province in Change (On the Treshold Between the $10^{\text {th }}$ and $11^{\text {th }}$ Century, Belgrade 2008.

Leksykon tradycji butgarskiej, red. G. Szwat-Gyłybowa, Warszawa 2011.

Leszka Mirosław J., Wizerunek władców pierwszego państwa butgarskiego w bizantyńskich źródtach pisanych (VIII - pierwsza polowa XII wieku), Łódź 2003.

Leszka Mirosław J., Symeon I Wielki a Bizancjum. Z dziejów stosunków bułgarsko-bizantyńskich w latach 893-927, Łódź 2013.

Leszka Mirosław J., Gabriel Radomir (1014-1015) i Jan Władysław (1015-1018), władcy państwa butgarskiego w źródtach bizantyńskich, „Balcanica Posnaniensia. Acta et studia”, 25, 2018, s. 4351.

Leszka Mirosław J., Marinow Kirył, Carstwo bułgarskie. Polityka - społeczeństwo - gospodarka - kultura. 866-971, Warszawa 2015.

Leśny Jan, Państwo Samuela a jego zachodni sąsiedzi, „Balcanica Posnaniensia. Acta et Studia”, 2, 1985, s. $87-112$.

Litavrin Gennadij, Bolgarija i Vizantija v XI-XII vv., Moskva 1960, [Г.Г., Литаврин, Болгария и Византия в XI-XII вв., Москва 1960.]

Madjarov Dzheny, L'histoire de Petãr (Pierre) Deljan - souverain legitime et du prince Arpad - dûla. Relations entre le ritual et la titulature, "Bulgarian Historical Review", 1, 2011, 1-2, s. 3-40.

Magdalino Paul, The Byzantine aristocratic oikos, w: The Byzantine Aristocracy IX to XIII Centuries, ed. M. Angold, Oxford 1984, s. 92-105.

Maksimović Ljubomir, Organiazacija vizantijskie vlasti u novoosvojenim oblastima posle 1018 godine, „Zbornik Radova Vizantološkog Instituta”, 36, 1997, s. 38-42, [Љ. Максимовиђ, Организация византийске власти у новоосвојеним областима после 1018. гоине, ЗРВИ, 36, 1997, s. 38-42]

Majewski Piotr, (Re)konstrukcje narodu. Odwieczna Macedonia powstaje w XXI wieku, Gdańsk 2013.

McKitterick Rosamond, Królestwa Karolingów. Władza - konflikty - kultura. 751-987, przekł. B. Hlebowicz, M. Wilk, Warszawa 2011.

Miodyński Lech, Symbole miejsca w kulturze i literaturze macedońskiej, Katowice 2011.

Miltenova Anisava, Kaimakamova Miljana, The Uprising of Petar Deljan (1040-1041) in a new Old Bulgarian Source, "Byzantinobulgarica", 8, 1986, s. 227-240.

Mochov Anton, Komandnyj sostav vizantijskoj armii v XI v. Pravlenije Romana III Argira (1028-1034), “Antičnaja drevnost' i srednije veki”, 31, 2000, s. 173-197, [А. Мохов, Командый состав византийской армии в XI в. Правление Романа III Аргира (1028-1034), „Античная древость и средние века", 31, 2000, s. 173-197] .

Moravcsik Gylia, Byzantinoturcica. II. Sprachreste der Türkvölker in den byzantinischen Quellen, Berlin 1983.

Nikolov Georgi N., Centralizm i regionalizm v rannosrednovekovna Bălgarija, Sofija 2005, [Г. Н. Николов, Централизъм и регионализм в ранносредновековна България, София 2005.]

Nikolov Georgi N., The Bulgarian aristocracy in the war against the Byzantine Empire (971-1019), w: Byzantium and East Central Europe, ed. G. Prinzing, M. Salamon, P. Stephenson, Cracov 2001, s. $141-158$.

Nikolov Angel, On Basil II's cognomen ,, The Bulgar-Slayer”, w: Европейският Югоизток, s. 578-584

Nikolowa Bistra, Monašestvo, manastiri i manastirski život v srednovekovna Bălgarija, t. I, Manastirite, t. II, Monasite, Sofija 2010, [Николова Б., Монашество, манастири и манастирски живот в средновековна България, t. I, Монастирите, t. II, Монасите, София 2010.] 
Paroń Aleksander, Pieczyngowie. Koczownicy w krajobrazie politycznym i kulturowym średniowiecznej Europy, Wrocław 2015.

Petrovski Boban, Central-southern Europe under the restored Byzantine administration after the fall of Samuel state, w: Jevropejskiat Jugoiztok prez vtorata polovina na X-načaloto na XI vek. Istorija i kultura, s. 266-276.

Pirivatrić Srđan, Samuilova država. Obim i karakter, Belgrad 1997, [С. Пириватрић, Самуилова држсава. Обим и карактер, Београд 1997.]

Pirivatric Srđan, Personal names in the ruling familie of the First Bulgarian Empire in the second half of $10^{\text {th }}$ and the early $11^{\text {th }}$ centurie. Some observations on their political implications, w: Jevropejskiat Jugoiztok prez vtorata polovina na X-načaloto na XI vek, s. 585-596.

Pleszczyński Andrzej, Kryzys i upadek wczesnych państw stowiańskich oraz ich odbudowa (IX-XI wiek). Zarys problemu, „Kwartalnik Historyczny”, 125, 2018, 2, s. 263-302.

Pohl Walter, Die Awaren. Ein Steppenvolk in Mitteleuropa. 567-822 n. Chr., München 1988.

Regesten der Kaiserukunden des oströmischen Reiches von 565-1453, berabeitet von F. Dölger, A.E. Müller, A. Beihammer, 1 Teil, 2 Halband Regesten 867-1025, München 2003; berabeitet von F. Dölger, Teil 3. Regesten 1204-1282, München - Berlin 1932.

Rek Stanisław, Powstanie zachodniobułgarskiego państwa Komitupulów, „Przegląd Historyczny”, 64, 1983, 2, s. 237-254.

Runciman Steven, A history of the first Bulgarian empire, London 1930.

Schulz Cordula, Probleme bei der Erforschung der Integration Bulgariens in das Byzantinische Reich, 1018-1186, w: Zwischen Polis, Provinz und Peripherie. Beiträge zur byzantinischen Geschichte und Kultur, ed. L.M. Hoffmann, A. Monchizadeh, Wiesbaden 2005, s. 337-347.

Seibt Walter, Untersuchungen zur vor- und Frühgeschichte der „,bulgarischen” Kometopulen, „Handes Amsorya", 89, 1975, s. 66-100.

Shepard Jonathan, A suspected source of Scylitzes? "Synopsis Historion": the great Catacalon Cecaumenus, "Greek, Roman and Byzantine Studies", 18, 1992, s. 171-181.

Slavova Tatjana, Vladetel i administracija v rannosrednovekovna Bălgarija. Filologičeski aspect, [Т. Славова, Владетел и администрачия в ранносредновековна България. Филологически аспекти, София 2010.]

Snegarov Ivan, Istorija na ochridskata archiepiskopija, t. 1, Ot osnovaneto na Balkanskija poluostrov ot Turcite, Sofija 1995, [И. Снегаров, История на охридската архиепископия. Том 1. От основаването ѝ до завладяването на Балканския полуостров от туриите, София 1995.]

Stepanenko Valery, John Vladislav dynasty (Vladislavichi), Arcrunids, Bagratids in the Byzantium of $11^{\text {th }}$ Century, “Antičnaja drevnost' i srednije veki”, 43, 2015, s. 178-191, [В.П. Степаненко, Владиславичи, Арируниды и Багратиды в Византии XI в., „Античная древость и средние века”, 43, 2015, s. 178-191.]

Stepanov Tsvetelin, From ,steppe” to Christian empire and back: Bulgaria between 800 and 1100, w: The Other Europe in the Middle Ages. Avars, Bulgars, Khazars, and Cumans, To the memory of Petre Diaconu (1927-2007), ed. F. Curta with the assistance of R. Kovalev, Leiden-Boston 2008, s. $363-$ 377.

Stephenson Paul, Byzantine Policy towards Paristrion in the mild-eleventh: another interpretation, „Byzantine and Modern Greek Studies", 22, 1999, s. 43-66.

Stephenson Paul, The Legend of Basil the Bulgar-Slayer, Cambridge 2003.

Ševčenko Ihor, The Illuminators of the Menologium of Basil II, „Dumbarton Oaks Papers”, 16, 1962, s. 345-276.

Tăpkova-Zaimova Vasilka, The Du Cange Catalogue, w: State and Church. Studies in Mediewal Bulgaria and Byzantium, ed. by V. Gjuzelev and K. Petkov, Sofija 2011, s. 209-235.

Tăpkova-Zaimova Vasilka, "Bălgari rodom...". Komitopulite, car Samuil i njegovite potomci spored istoričeski izvori i istoriografskata tradicija, Sofija 2014, [Тъпкова-Заимова В., „Българи родом... ". Комитопулите, ичар Самуил и неговите потомичи според историческите извори и историогрфската традиция, София 2014]. 
The Bulgarian State in 927-969. The Epoch of Tsar Peter I, ed. M.J. Leszka, K. Marinow, Łódź-Kraków 2018.

Treštík Dušan, Pád Velké Moravy, w: Typologie raně feudálních slovanských států. Sbornik př̀spěvků $z$ mezinárodni konferencje $k$ tématu „Vznik a rozvoj slavanských raně feudálních státu a národností ve středni a jihovýchodni Evropě", konané ve dnech 18.-20. listopadu 1986 v Praze, Praha 1987, s. $37-42$.

Wasilewski Tadeusz, Administracja bizantyńska na ziemiach stowiańskich i jej polityka wobec Stowian w XI-XII w., „Kwartalnik Historyczny”, 70, 1963, 2, s. 303-321.

Wojnowski Michał, Konnica w armii Cesarstwa Bizantyńskiego od VIII do XIII w. Rola militarna i znaczenie spoleczne, Oświęcim 2014.

Ziemann Daniel, Between authoritarianism and consensus. Domination and the role of nobility in the First Bulgarian Realm (7th $-9^{\text {th }}$ Century), "Bulgaria Mediaevalis", 2, 2011 (1), s. 373-397.

Ziemann Daniel, The rebellion of the nobles against the baptism of Khan Boris (865-866), w: Post-Roman Towns, Trade and Settlement in Europe and Byzantium. Vol. 2. Byzantium, Pliska, and the Balkans, ed. J. Henning, Berlin - New York 2007, s. 613-624.

Zlatarski Vasyl, Ustrojstwo Bolgarii i položenije bolgarskogo naroda w pervoje vremja posle pokorenija ich Wasilijem II Bolgarobojceju, w: V. Zlatarski, Izbrani proizvedenija, t. II, Sofija 1984, [В. Златарски, Устройство Болгарии и положение болгарского народа в первое время после покорения их Василием II Болгаробойцею, „Seminarium Kondakovianum”, t. 4, Praha, 1931, s. 49-67, [przedruk: В. Златарски, Избрани произведения, t. II, София 1984, s. 120-140]. 
